\title{
Understanding Conflicts of Interest in Environmental Law
}

\author{
Douglas R. Richmond*
}

\section{INTRODUCTION}

Conflicts of interest pose recurring professional responsibility and practice management challenges for lawyers and are a persistent source of professional liability exposure. Conflicts of interest may spawn breach of fiduciary duty and professional negligence allegations, require lawyers to decline potentially lucrative representations, disqualify lawyers from representations or force their withdrawal from cases, compel law firms to disgorge fees, bruise lawyers' relationships with clients, and generate negative publicity that may at least temporarily harm law firms' reputations. Predictably, then, law firm general counsels rank conflicts of interest among their top risk management concerns. ${ }^{1}$

At the same time, law firm general counsels understandably cite conflicts as the one area in which lawyers require the most education. ${ }^{2}$ Conflicts of interest are often complicated. There are some bright line rules, such as a lawyer's inability to represent both the plaintiff and the defendant in the same case, but many answers to conflicts questions are unclear. Who is the client? What is direct adversity? When do lawyers' relationships with current clients, former clients, or third parties create a substantial risk of material limitations in proposed concurrent representations? When does a client's consent to a conflict of interest qualify as informed? In the case of former client conflicts, when are successive matters substantially related? The list of questions goes on.

Although conflicts of interest arise in all practice areas, they seem to pervade environmental matters. ${ }^{3}$ Experienced environmental lawyers

\footnotetext{
* Managing Director, Aon, Kansas City, Missouri. J.D., University of Kansas. Opinions expressed here are solely those of the author.

1. Matthew K. Corbin, The Aon General Counsel Survey, Quality Assurance Rev. (Aon plc, Chi., Ill.), Summer 2016, at 1, 20-21 (ranking conflicts of interest as one of law firm general counsels' top three risk management concerns) (on file with the author).

2. Id. at 20-21.

3. IRMA S. RUSSELL, ISSUES OF LEGAL ETHICS IN THE PRACTICE OF ENVIRONMENTAL LAW 199
} 
assert that "environmental law poses especially difficult and complex" conflict questions. ${ }^{4}$ There are several reasons for this claim. First, "[t]he complexity and size of a typical environmental proceeding combined with a relatively small number of qualified [law] firms increases the likelihood of a conflict of interest." 5 For example, the federal Comprehensive Environmental Response, Compensation and Liability Act, or CERCLA, establishes a liability regime for the remediation of hazardous waste facilities (often named as Superfund sites) under which scores of potentially responsible parties (PRPs) identified in a cost recovery action initiated by the Environmental Protection Agency (EPA) may have competing interests. ${ }^{6}$ For a law firm with a significant environmental law practice, any Superfund case is reasonably likely to involve more than one of its existing clients as a PRP or to draw requests for representation from multiple PRPs who would become new clients, or both, and all of whom may at some point be adverse to one another.

Second, and relatedly, multiple PRPs may form joint defense groups or similar alliances that employ common counsel, or which share confidential information among separately represented members, or both. A lawyer's employment as group counsel or receipt of confidential information from a party in one matter may create conflicts of interest in subsequent matters that are substantially related to the first one. ${ }^{7}$ Indeed, allegations of former client conflicts of interest under Model Rule of Professional Conduct $1.9(a)^{8}$ and state counterparts regularly appear on the environmental law landscape. ${ }^{9}$

(2003).

4. Andrew Kenefick et al., Assessing Conflicts of Interest at Multi-Party Superfund Sites: From First Involvement to Litigation, 4 ENVTL. LAW. 721, 725 (1998).

5. Sanford M. Stein \& Jan M. Geht, Legal Ethics for Environmental Lawyers: Real Problems, New Challenges, and Old Values, 26 WM. \& MARY EnvTL. L. \& POL'Y Rev. 729, 731 (2002).

6. Kenefick et al., supra note 4, at 725 (stating that CERCLA and "state counterparts establish liability schemes whereby theoretically dozens, hundreds, or even thousands of parties can be adverse to every other party" (footnote omitted)); Stein \& Geht, supra note 5, at 731 (discussing CERCLA cases as breeding grounds for conflicts of interest and stating that the number of PRPs may "reach well into the hundreds," such that "[t]he greater number of PRPs increases the likelihood that a single firm would represent several parties" (footnote omitted)).

7. See, e.g., City of Kalamazoo v. Mich. Disposal Serv. Corp., 125 F. Supp. 2d 219, 231-43 (W.D. Mich. 2000) (disqualifying a law firm that served as common counsel for a joint defense group and received confidential information from group members); GTE N., Inc. v. Apache Prods. Co., 914 F. Supp. 1575, 1579-81 (N.D. Ill. 1996) (disqualifying a lawyer and his law firm based on an implied attorney-client relationship created during a joint pre-suit investigation).

8. Model Rules of Prof'L CONDUCT r. 1.9(a) (AM. BAR AsS'N 2019) (“A lawyer who has formerly represented a client in a matter shall not thereafter represent another person in the same or a substantially related matter in which that person's interests are materially adverse to the interests of the former client unless the former client gives informed consent, confirmed in writing.").

9. RUSSELL, supra note 3, at 245. 
Third, because in some areas environmental law expertise is concentrated in a few lawyers or law firms, a lawyer who advised a client in connection with a matter may later find herself materially adverse to that client on behalf of a second client in what is alleged to be a substantially related matter. Sometimes the conflict may be a product of the lawyer moving laterally between law firms. Regardless, if the two matters are, in fact, substantially related, the lawyer and her law firm will be guilty of a former client conflict of interest and in many cases be disqualified from participating in the second matter. ${ }^{10}$

This Article explores common conflicts of interest in environmental law practice. Part II addresses the first step in any conflict of interest analysis - identifying and classifying the clients. In doing so, it discusses the general rules for establishing and terminating attorney-client relationships. Part III examines concurrent client conflict of interest issues. These include direct adversity conflicts, material limitation conflicts, conflicts of interest arising out of Superfund litigation, obtaining clients' informed consent to conflicts of interest, and the enforceability of advance conflict waivers. Part IV explores fundamental former client conflict of interest issues, focusing on the substantial relationship test for former client conflicts under Model Rule of Professional Conduct 1.9(a). ${ }^{11}$ Part IV also analyzes former client conflicts linked to lawyers' lateral movement, including imputed disqualification and screening issues, and the meaning of "material adversity" for former client conflict purposes. Finally, Part V analyzes issue or positional conflicts of interest.

10. See, e.g., Lane v. BP p.l.c., No. 15-CV-524-TCK-FHM, 2018 WL 4932002, at *4-6 (N.D. Okla. Oct. 11, 2018) (involving a lawyer who acquired confidential client information and subsequently moved laterally, and rejecting the plaintiffs' argument that the defendant waived the former client conflict by waiting more than one year before moving to disqualify the lawyer); Roosevelt Irrigation Dist. v. Salt River Project Agric. Improvement \& Power Dist., 810 F. Supp. 2d 929, 945-75 (D. Ariz. 2011) (disqualifying the law firm in CERCLA litigation because of the lawyers' prior representations of two PRPs in connection with groundwater contamination allegedly emanating from their properties); Stimson Lumber Co. v. Int'l Paper Co., No. CV 10-79-M, 2011 WL 124303, at $* 2-5$ (D. Mont. Jan. 14, 2011) (involving a lawyer who moved laterally and his new firm's ineffective attempt to screen him from participation in a private cost recovery action, resulting in the law firm's disqualification); Lyondell Chem. Co. v. Ablemarle Corp., No. 1:01-CV-890, 2004 WL 7332836, at *6-9 (E.D. Tex. Feb. 23, 2004) (focusing on the client's confidential information revealed to the lawyer in the prior representation). But see New York v. Monfort Tr., No. CV 12 3755(LDW)(SIL), 2014 WL 5018607, at *3-6 (E.D.N.Y. Oct. 7, 2014) (discussing New York ethics rules in connection with a CERCLA case and declining to disqualify the lawyer because the lawyer's conflict did not taint the proceedings).

11. Model Rules of Prof'L Conduct r. 1.9(a) (AM. BAR Ass'N 2019). 


\section{IDENTIFYING AND CLASSIFYING CLIENTS}

The essential first step in any conflict of interest analysis is to know who the lawyer represents. It is, after all, clients to whom lawyers owe duties of confidentiality and loyalty, which underpin conflict of interest rules. ${ }^{12}$ In most cases, client identities are clear. The existence of an attorney-client relationship, or a person's or entity's status as a current or former client, can be answered by reviewing the terms of the lawyer's engagement (or disengagement) letter. ${ }^{13}$ But not all cases are so straightforward. Indeed, an attorney-client relationship may arise in the absence of an express contract between the lawyer and the client. ${ }^{14}$

State substantive law, rather than rules of professional conduct, typically governs whether parties have an attorney-client relationship. ${ }^{15}$ The existence of an attorney-client relationship, or conversely, the absence

12. See Dynamic 3D Geosols. LLC v. Schlumberger Ltd., 837 F.3d 1280, 1286 (Fed. Cir. 2016) ("[T]here is an overriding countervailing concern suffusing the ethical rules: a client's entitlement to an attorney's adherence to her duty of loyalty, encompassing a duty of confidentiality.... Accordingly, the obligation to protect a client's confidential information exists as part of the larger duty of loyalty owed to clients to maintain the integrity of the attorney-client relationship." (citations omitted)); Antelope Valley-E. Kern Water Agency v. L.A. Cty. Waterworks Dist. No. 40 (Antelope Valley Groundwater Cases), 241 Cal. Rptr. 3d 692, 702 (Ct. App. 2018) ("The restrictions on an attorney's ability to represent clients with interests that are potentially or actually adverse are designed to protect two distinct values: to assure the attorney represents his or her client with undivided loyalties, and to assure the attorney will preserve confidential information conveyed by the client to the attorney." (citations omitted)); N.J. Div. of Child Prot. \& Permanency v. G.S., 149 A.3d 816, 831 (N.J. Super. Ct. App. Div. 2016) ("The risk in representing clients with conflicting interests is that a lawyer's divided loyalty will result in less vigorous representation of both clients, and that the lawyer will use confidences of one client to benefit the other." (citation omitted)); RONALD D. ROTUNDA \& John S. DZIENKowski, Legal ETHICS: THE LAWYeR's DeskboOK ON PROFESSIONAL RESPONSIBILITY $\S 1.7-1$, at 361 (2018-2019) ("The rules governing conflicts of interest derive, in large part, from the need to protect client confidences and secrets and the need to assure clients that they have their lawyer's loyalty." (footnote omitted)). A concurrent conflict of interest is one in which "the interests of two current clients are at odds," while a former client conflict places a lawyer's former client's interests at odds with those of a current client. Lennar Mare Island, LLC v. Steadfast Ins. Co., 105 F. Supp. 3d 1100, 1108 (E.D. Cal. 2015). In a concurrent client conflict, it is principally the lawyer's duty of loyalty - and the clients' expectation of loyalty - that are at stake. Id. (quoting Robert Bosch Healthcare Sys., Inc. v. Cardiocom, LLC, No. C-14-1575, 2014 WL 2703807, at *3 (N.D. Cal. June 13, 2014)). In a former client conflict—where the lawyer's representations are successive rather than concurrent - courts are chiefly concerned about preserving the lawyer's duty of confidentiality to the former client. Id. "Nevertheless, the duty of confidentiality and loyalty apply in both concurrent and successive cases." Id.

13. See, e.g., Avocent Redmond Corp. v. Rose Elecs., 491 F. Supp. 2d 1000, 1004 (W.D. Wash. 2007) (deciding whether an attorney-client relationship exists should ordinarily begin with a review of the engagement agreement because its terms are accorded significant weight in examining the scope of the relationship).

14. Bistline v. Parker, 918 F.3d 849, 864 (10th Cir. 2019) (applying Utah law).

15. United States v. Williams, 720 F.3d 674, 686 (8th Cir. 2013); Rozmus v. West, 13 Vet. App. 386, 387 (2000). 
of one, depends on the facts and circumstances of the case. ${ }^{16}$ That said, some guidelines concerning the creation and termination of an attorneyclient relationship are useful to the overall client identity analysis.

\section{A. Establishing an Attorney-Client Relationship}

An attorney-client relationship may be expressly created through a written or oral contract. ${ }^{17}$ The execution of an engagement agreement or the payment of legal fees is significant when determining whether an attorney-client relationship exists. ${ }^{18}$ At the same time, these formalities are not essential because an attorney-client relationship may be implied or inferred from the parties' conduct. ${ }^{19}$ Certainly, the payment of fees does not alone create an attorney-client relationship. ${ }^{20}$

When deciding whether an implied attorney-client relationship exists, courts focus on the would-be client's expectations and especially the reasonableness of the person's "belief that he is consulting a lawyer in that capacity and his manifested intention to seek professional legal advice." 21 Even applying this seemingly generous standard, however, a putative client's unilateral belief that an attorney-client relationship exists is insufficient to establish such a relationship. ${ }^{22}$ Rather, a putative client's subjective expectation that an attorney-client relationship has been formed must be accompanied by facts indicating that the person's belief is

16. In re Robbins, 192 A.3d 558, 563 (D.C. 2018); Valliere v. Fla. Elections Comm'n, 989 So. 2d 1242, 1243 (Fla. Dist. Ct. App. 2008); Newsome v. Peoples Bancshares, 269 So. 3d 19, 31 (Miss. 2018); Rice v. Neether, 888 N.W.2d 749, 755 (N.D. 2016).

17. See, e.g., Cleveland Campers, Inc. v. R. Thad McCormack, P.C., 635 S.E.2d 274, 276 (Ga. Ct. App. 2006) (noting that "an attorney-client relationship generally is a matter of express contract"); Walker v. Elkin, 758 N.E.2d 972, 974-75 (Ind. Ct. App. 2001) (finding that the lawyer entered into an oral contract to represent the plaintiff's son); State ex rel. Stivrins v. Flowers, 729 N.W.2d 311, 317 (Neb. 2007) (reasoning that an attorney-client relationship existed where the client asked the lawyer to represent him at a deposition and the lawyer agreed to do so).

18. Avocent Redmond Corp., 491 F. Supp. 2d at 1004; Mays v. Askin, 585 S.E.2d 735, 737 (Ga. Ct. App. 2003); Patel v. Martin, 111 N.E.3d 1082, 1095 (Mass. 2018).

19. Stewart v. McDonald, 815 S.E.2d 665, 671-72 (Ga. Ct. App. 2018) (quoting Cleveland Campers, Inc., 635 S.E.2d at 276); In re Hodge, 407 P.3d 613, 648 (Kan. 2017); Patel, 111 N.E.3d at 1093.

20. Edward Wildman Palmer LLP v. Supererior Court, 180 Cal. Rptr. 3d 620, 628 (Ct. App. 2014); Rubin \& Norris, LLC v. Panzarella, 51 N.E.3d 879, 891 (Ill. App. Ct. 2016); State ex rel. Stovall v. Meneley, 22 P.3d 124, 140 (Kan. 2001); Att'y Grievance Comm'n of Md. v. Brooke, 821 A.2d 414, 424 (Md. 2003); Fuller v. Partee, 540 S.W.3d 864, 869 (Mo. Ct. App. 2018) (quoting Fox v. White, 215 S.W.3d 257, 261 (Mo. Ct. App. 2007)); In re Disciplinary Action Against Ward, 881 N.W.2d 226, 229-30 (N.D. 2016).

21. Diversified Grp., Inc. v. Daugerdas, 139 F. Supp. 2d 445, 454 (S.D.N.Y. 2001) (quoting Westinghouse Elec. Corp. v. Kerr-McGee Corp., 580 F.2d 1311, 1319 (7th Cir. 1978)).

22. In re Rescue Concepts, Inc., 556 S.W.3d 331, 339 (Tex. App. 2017). 
objectively reasonable. ${ }^{23}$ At base, then, the existence of an attorney-client relationship is measured by an objective standard. ${ }^{24}$

By requiring evidence establishing the reasonableness of the aspiring client's subjective belief that an attorney-client relationship exists-that is, by overlaying an objective standard - courts ensure that an attorneyclient relationship arises only when both the attorney and client consent to its formation. ${ }^{25}$ For example, a person's subjective belief may be deemed reasonable where the surrounding facts and circumstances place the lawyer on notice that the person intended to form an attorney-client relationship, indicate that the lawyer shared the person's subjective intent to create the relationship, or demonstrate that the lawyer acted in a manner that would prompt a reasonable person in the putative client's position to rely on the lawyer's professional advice. ${ }^{26}$ Similarly, if a lawyer holds herself out to third parties as representing a person, or acts on behalf of that person, these steps may evidence an attorney-client relationship. ${ }^{27}$

Evraz Inc., N.A. v. Continental Insurance $\mathrm{Co}^{28}$ is a relatively recent case arising out of Superfund litigation in which the court declined to recognize an attorney-client relationship. The plaintiff, Evraz, was locked in a contract dispute with several insurance companies over their alleged breach of their duty to defend it in the so-called Portland Harbor Superfund litigation. ${ }^{29}$ Evraz sought leave to replace its law firm in the breach of

23. Hinerman v. Grill on Twenty First, LLC, 112 N.E.3d 1273, 1275-76 (Ohio Ct. App. 2018); Jensen v. Hillsboro Law Grp., PC, 403 P.3d 455, 461 (Or. Ct. App. 2017). See, e.g., E.P. v. Hogreve, 259 So. 3d 1007, 1011 (Fla. Dist. Ct. App. 2018) (explaining that the plaintiffs had "alleged sufficient facts to demonstrate their reasonable belief that they were consulting with [the lawyer] to obtain legal advice," such that they shared an attorney-client relationship).

24. Barkerding v. Whittaker, 263 So. 3d 1170, 1182 (La. Ct. App. 2018).

25. See Cohen v. Jaffe Raitt Heuer \& Weiss, P.C., 768 F. App'x 440, 444 (6th Cir. 2019) (recognizing that "attorney-client relationships require mutual assent. ... [O]ne party alone cannot create an attorney-client relationship"); People v. Shepherd, 99 N.E.3d 513, 518 (Ill. App. Ct. 2018) ("Although an attorney-client relationship requires no formal written agreement or payment ... both the attorney and the client must express their intent to form it. The relationship is voluntary and contractual; it requires both parties' consent." (citations omitted)); In re Kinney, 670 N.E.2d 1294, 1297 (Ind. 1996) ("The [attorney-client] relationship is consensual, existing only after both attorney and client have consented to its formation." (citations omitted)).

26. DG Cogen Partners, LLC v. Lane Powell PC, 917 F. Supp. 2d 1123, 1137 (D. Or. 2013) (quoting In re Conduct of Weidner, 801 P.2d 828, 837 (Or. 1990)).

27. See, e.g., In re Persaud, 467 B.R. 26, 40 (Bankr. E.D.N.Y. 2012) (explaining that regular communications relating to the subject of the representation as well as activity by the lawyer and the client in furthering the objectives of the representation are pertinent to the analysis); Heine v. Colton, Hartnick, Yamin \& Sheresky, 786 F. Supp. 360, 367 (S.D.N.Y. 1992) (noting that a lawyer creates a presumption of an attorney-client relationship by entering an appearance in a proceeding); Davis v. State Bar, 655 P.2d 1276, 1278-79 (Cal. 1983) (mailing letters to third-parties in which the lawyer claimed that he represented the client evidenced an attorney-client relationship).

28. No. 3:08-cv-00447-AC, 2013 WL 6174839 (D. Or. Nov. 21, 2013).

29. Id. at *1. 
contract case against the insurers, Gorden Tilden Thomas \& Cordell LLP, with Stoel Rives LLP. ${ }^{30}$ Defendant Continental Insurance Co. (Continental) opposed Evraz's motion in part because it allegedly would create a conflict of interest. ${ }^{31}$ In a nutshell, Continental claimed that because Stoel Rives was defending Evraz in the Portland Harbor Superfund litigation and Continental was reimbursing Evraz for the cost of that defense, Continental and Stoel Rives shared an attorney-client relationship. ${ }^{32}$ Therefore, Stoel Rives could not represent Evraz against it in the litigation at hand. ${ }^{33}$

During the Portland Harbor Superfund litigation, the lead lawyer for Stoel Rives repeatedly advised Continental that the firm considered Evraz to be its client and that the firm was acting solely on Evraz's behalf. ${ }^{34}$ In the breach of contract case, Evraz contended that under Oregon law, Stoel Rives and Continental never formed an attorney-client relationship and thus there could be no conflict of interest that would prohibit it from employing Stoel Rives in its lawsuit with Continental. ${ }^{35}$ To the contrary, Continental argued, there was "a default rule in Oregon that govern[ed] insurance duty-to-defend cases, and under this rule an attorney-client relationship automatically arose between Continental and Stoel Rives when Continental began 'funding' Evraz's defense."36

The Evraz court observed that in a case styled In re Weidner,${ }^{37}$ the Oregon Supreme Court held that an attorney-client relationship can be implied where (1) the aspiring client subjectively believes an attorneyclient relationship exists; and (2) that belief is objectively reasonable. ${ }^{38}$ As the Evraz court viewed the evidence, Continental failed both prongs of the In re Weidner test for an implied attorney-client relationship with Stoel Rives. ${ }^{39}$

First, there was no evidence to support Continental's claimed subjective belief that it shared an attorney-client relationship with Stoel Rives. ${ }^{40}$ Stoel Rives repeatedly told Continental that it represented Evraz alone in the Portland Harbor Superfund litigation and Continental never




disputed those assertions. ${ }^{41}$ Furthermore, Continental never acted as though it had a typical insurance defense relationship with Stoel Rives that might suggest an attorney-client relationship. ${ }^{42}$ For example, virtually all of Continental's communications in the Portland Harbor Superfund litigation were with Evraz rather than Stoel Rives, including communications in which Continental challenged Stoel Rives's hourly rates and billing practices; Continental reimbursed Evraz for Stoel Rives's fees rather than paying Stoel Rives directly; and Continental and Stoel Rives did not communicate about the conduct or status of the defense of the Superfund case as might be expected in a normal insurance defense representation. ${ }^{43}$ Second, but along the same lines, there was no evidence that Continental's claimed belief that Stoel Rives represented it was objectively reasonable:

Continental produced no letter, memo, email, or other contemporaneous document from Stoel Rives that supports an objectively reasonable basis to conclude that Stoel Rives represented Continental. It produced no document from it to Stoel Rives claiming, expressly or implicitly, to be Stoel Rives's client, which Stoel Rives then should have corrected or refuted. Continental has produced no evidence of requests or demands to Stoel Rives' insisting on compliance with traditional insurancedefense relationship hallmarks such as creating litigation budgets, providing direct, regular status updates, setting maximize [sic] amounts for hourly rates, or requiring authorization from Continental before engaging in various litigation tasks. And, at the time Evraz tendered its defense to Continental, Stoel Rives had been representing Evraz in the Portland Harbor Superfund litigation for five years and Evraz generally since the early 1990s, an attorney-client relationship created without any involvement by or connection with Continental. ${ }^{44}$

Ultimately, the court concluded that there was no reason to prohibit Stoel Rives from representing Evraz in its lawsuit against Continental. ${ }^{45}$ The court accordingly granted Evraz's motion to substitute counsel. ${ }^{46}$

\section{B. Terminating the Attorney-Client Relationship}

Once an attorney-client relationship is established, the lawyer cannot easily end it. Lawyers may withdraw from representations only for good
41. Id.
42. Id.
43. Id.
44. Id. at *6.
45. Id. at $* 9$.
46. Id. 
reason and, at least insofar as litigation is concerned, upon reasonable notice. ${ }^{47}$ Moreover, in litigation, the court must grant the lawyer's motion to withdraw; until the court does so, the attorney-client relationship continues to the conclusion of the litigation. ${ }^{48}$ In contrast, a client may fire a lawyer at any time and for any reason, or for no reason. ${ }^{49}$

Courts regularly assess the ways in which an attorney-client relationship may conclude. The relationship clearly may terminate by the explicit statement of either the lawyer or the client. ${ }^{50}$ For example, a lawyer might specify in an engagement letter that her representation of the client will cease when she sends a final invoice for services or the lawyer might send a disengagement letter upon completion of the matter. Overt acts inconsistent with the continuation of the attorney-client relationship may also terminate the relationship. Examples of inconsistent conduct include the client filing a professional grievance against the lawyer, a client hiring another lawyer to perform the task for which the first lawyer was retained, or the client refusing to pay the lawyer's bill. ${ }^{51}$

Absent express statements or overt acts by either the lawyer or the client, an attorney-client relationship ends when circumstances imply that "it would be objectively unreasonable to continue to bind the parties to each other." ${ }^{52}$ When determining the posture of the attorney-client

47. See Model Rules of Prof'L Conduct r. 1.16(b) \& (c) (Am. BAR Ass'N 2019) (listing grounds for permissive withdrawal and requiring a lawyer to comply with applicable law requiring notice to, or permission of, a tribunal when terminating a representation).

48. State v. Payne, 855 N.W.2d 783, 787 (Neb. 2014).

49. White Pearl Inversiones S.A. (Uruguay) v. Cemusa, Inc., 647 F.3d 684, 689 (7th Cir. 2011); Nabi v. Sells, 892 N.Y.S.2d 41, 43 (App. Div. 2009); MODEL RULES OF PROF'L CONDUCT r. 1.16 cmt. 4 (AM. BAR ASS'N 2019).

50. See Artromick Int'l, Inc. v. Drustar, Inc., 134 F.R.D. 226, 229 (S.D. Ohio 1991) ("Of course, the simplest way for either attorney or client to end the relationship is by expressly saying so."); see, e.g., NuStar Farms, LLC v. Zylstra, 880 N.W.2d 478, 481 (Iowa 2016) (recounting that the lawyer informed the clients by email "that he would no longer be representing them in any future matters" and that the clients acknowledged that they understood the email message to sever the attorney-client relationship); Rusk v. Harstad, 393 P.3d 341, 344 (Utah Ct. App. 2017) (concluding that a would-be client could not have reasonably believed that the law firm represented him where the lawyer had clearly stated in multiple emails that the law firm would not represent him).

51. See Artromick Int'l, Inc., 134 F.R.D. at 230-31 (ruling that the alleged client was a former client because he had refused to pay the attorney's bill and thereafter retained other lawyers to work in areas which that attorney had previously performed); Waterbury Garment Corp. v. Strata Prods., 554 F. Supp. 63, 66 (S.D.N.Y. 1982) (concluding that a person was a former client because the law firm represented him only in discrete transactions that had concluded and the person had subsequently retained different counsel); DeLeo v. Nusbaum, 821 A.2d 744, 750 (Conn. 2003) ("A de facto termination [of the attorney-client relationship] occurs if the client takes a step that unequivocally indicates that he has ceased relying on his attorney's professional judgment in protecting his legal interests, such as hiring a second attorney to consider a possible malpractice claim or filing a grievance against the attorney." (footnotes omitted)).

52. Artromick Int'l, Inc., 134 F.R.D. at 230 
relationship on an implied basis, the parties' reasonable expectations often hinge on the scope of the lawyer's representation. ${ }^{53}$ In that regard, the scope of a lawyer's representation loosely falls into one of three categories: (1) the client hires the lawyer as general counsel with the expectation that the lawyer will handle all the client's potential legal matters; (2) the client retains the lawyer to handle all matters that arise in a specific practice area, such as employment, litigation, real estate, or tax; (3) or the client engages the lawyer to represent the client in a discrete matter or matters. ${ }^{54}$ For all three categories, unless the client fires the lawyer or the lawyer withdraws from the representation, the attorneyclient relationship continues as long as the lawyer remains responsible for an open matter because the lawyer "has accepted responsibility for bringing the matter to a successful conclusion." 55 With respect to categories one and two, an attorney-client relationship exists even if the lawyer has no pending matter for the client because the client still reasonably expects that the lawyer will handle matters for the client as they arise. ${ }^{56}$ In the third category, where a lawyer agrees to undertake a specific matter on the client's behalf, the attorney-client relationship typically ends once the matter is concluded. ${ }^{57}$

\section{CONCURRENT CLIENT CONFLICTS OF INTEREST}

Once clients are identified and classified, it is time to examine potentially applicable rules of professional conduct. Where current clients are concerned, conflicts of interest are governed by Model Rule of Professional Conduct 1.7, which provides:

\section{Id.}

54. Nat'l Med. Care, Inc. v. Home Med. of Am., Inc., No. 00-1225, 2002 WL 31068413, at *4 (Mass. Super. Ct. Sept. 12, 2002).

55. Id.

56. Id.; see also Berry v. McFarland, 278 P.3d 407, 411 (Idaho 2012) (explaining that if a lawyer agrees to handle any matters a client may have, the attorney-client relationship continues until either the lawyer or client terminates it); MODEL RULES OF PROF'L CONDUCT r. $1.3 \mathrm{cmt}$. 4 (AM. BAR Ass'N 2019) ("If a lawyer has served a client over a substantial period in a variety of matters, the client sometimes may assume that the lawyer will continue to serve on a continuing basis unless the lawyer gives notice of withdrawal.").

57. Nat'l Med. Care, Inc., 2002 WL 31068413, at *4; Simpson v. James, 903 F.2d 372, 376 (5th Cir. 1990); DeLeo v. Nusbaum, 821 A.2d 744, 750 (Conn. 2003); Berry, 278 P.3d at 411; MoDEL RULES OF PROF'L CONDUCT r. 1.3 cmt. 4 (AM. BAR Ass'N 2019); see also Revise Clothing, Inc. v. Joe's Jeans Subsidiary, Inc., 687 F. Supp. 2d 381, 389 (S.D.N.Y. 2010) (noting that an attorney-client relationship is ordinarily terminated by the accomplishment of the purpose for which it was formed); Thayer v. Fuller \& Henry Ltd., 503 F. Supp. 2d 887, 892 (N.D. Ohio 2007) (observing that an attorneyclient relationship may terminate "when the underlying action has concluded or when the attorney has exhausted all remedies in the case and had declined to provide additional legal services on related issues" (quoting Busacca v. Maguire \& Schneider, LLP, 834 N.E.2d 856, 860 (Ohio Ct. App. 2005))). 
(a) Except as provided in paragraph (b), a lawyer shall not represent a client if the representation involves a concurrent conflict of interest. A concurrent conflict of interest exists if:

(1) the representation of one client will be directly adverse to another client; or

(2) there is a significant risk that the representation of one or more clients will be materially limited by the lawyer's responsibilities to another client, a former client or a third person or by a personal interest of the lawyer.

(b) Notwithstanding the existence of a concurrent conflict of interest under paragraph (a), a lawyer may represent a client if:

(1) the lawyer reasonably believes that the lawyer will be able to provide competent and diligent representation to each affected client;

(2) the representation is not prohibited by law;

(3) the representation does not involve the assertion of a claim by one client against another client represented by the lawyer in the same litigation or other proceeding before a tribunal; and

(4) each affected client gives informed consent, confirmed in writing. ${ }^{58}$

Conflicts of interest arising under Model Rule 1.7(a)(1) are generally characterized as "direct adversity" conflicts, while those arising under Model Rule 1.7(a)(2) are frequently described as "material limitation" conflicts.

Whether clients are concurrent clients and therefore whether a conflict of interest should be evaluated under Model Rule 1.7 is determined at the time the alleged conflict arose. ${ }^{59}$ Were the approach otherwise, a lawyer could simply stop representing the less valuable or less desirable client and trigger the more lenient client conflict of interest test applied where a former client is concerned. ${ }^{60}$

Importantly, the restrictions that Model Rule 1.7(a) imposes on

58. Model Rules of Prof'L CONDUCT r. 1.7 (AM. BAR ASS'N 2019).

59. First NBC Bank v. Murex, LLC, 259 F. Supp. 3d 38, 68 (S.D.N.Y. 2017) (involving a large law firm that in addition to representing the bank in this case concurrently represented the defendant in a threatened EPA enforcement action). See, e.g., NuStar Farms, LLC v. Zylstra, 880 N.W.2d 478, 484-85 (Iowa 2016) (finding that a direct adversity concurrent client conflict of interest existed because the lawyer formed the intent to pursue legal action against his clients before he terminated the attorney-client relationship).

60. First NBC Bank, 259 F. Supp. 3d at 68 (quoting Merck Eprova AG v. ProThera, 670 F. Supp. 2d 201, 209 (S.D.N.Y. 2009)); Markham Concepts, Inc. v. Hasbro, Inc., 196 F. Supp. 3d 345, 349 (D.R.I. 2016). 
individual lawyers generally apply equally to law firms. This is because, with some exceptions, individual lawyers' conflicts of interest are imputed to all other lawyers in the same firm. ${ }^{61}$

\section{A. Direct Adversity Conflicts}

As noted above, Model Rule 1.7(a)(1) first establishes that a lawyer has a conflict of interest when "the representation of one client will be directly adverse to another client." 62 The rule does not attempt to define "direct adversity" or to explain when concurrent representations are "directly adverse," although the comments to Model Rule 1.7 offer examples. ${ }^{63}$ Some courts have attempted to define direct adversity, although they have not necessarily achieved clarity in doing so. For example, the Massachusetts Supreme Judicial Court has stated that direct adversity "involves a conflict between the legal rights and duties of clients." ${ }^{64}$ In any event, Model Rule 1.7(a)(1)'s use of the adverb "directly" to modify "adverse" separates these conflicts from other conflicts premised upon clients' general or indirect adversity. ${ }^{65}$ In addition, Rule 1.7(a)(1) only operates when concurrent clients' interests "will be" directly adverse. ${ }^{66}$ This language excludes "the mere possibility of 'directly adverse' interests and inserts another factor of reasonable probability in the determination." 67

61. Model Rules of Prof'L CONDUCt r. 1.10(a) (AM. BAR ASS'N 2019); see also Ex parte Osbon, 888 So. 2d 1236, 1238 (Ala. 2004) (asserting that "Rule 1.10(a) requires a law firm to be treated as a single attorney").

62. Model Rules of PROF'L CONDUCt r. 1.7(a)(1) (AM. BAR ASS'N 2019).

63. Id. r. 1.7 cmts. 6 \& 7.

64. Bryan Corp. v. Abrano, 52 N.E.3d 95, 103 (Mass. 2016) (citing Maling v. Finnegan, Henderson, Farabow, Garrett, \& Dunner, LLP, 42 N.E.3d 199, 204 (Mass. 2015)).

65. Chapman Eng'rs, Inc. v. Nat. Gas Sales Co., 766 F. Supp. 949, 956 (D. Kan. 1991) (citing 1 GeofFrey C. HaZARD, JR. \& W. William Hodes, The LaW OF LAWYering § 1.7:203 (1990)); Ill. State Bar Ass'n Prof'l Conduct, Adv. Op. 95-15, at 4 (1996), https://www.isba.org/sites/default/ files/ethicsopinions/95-15.pdf [https://perma.cc/BT26-6KBK] (interpreting the choice of the modifier "directly" to define adversity to "exclude indirect, derivative, and other speculative impacts of the lawyer's activity" because otherwise "any conceivable impact on a client, however slight or implausible, would have to be taken as impermissible, direct adversity").

66. Model RULES OF PROF'L CONDUCT r. 1.7(a)(1) (AM. BAR ASs'N 2019).

67. Chapman Eng'rs, Inc., 766 F. Supp. at 956 (citing HAZARD \& HODES, supra note 65, at 233)). See, e.g., Ramos v. Pabey, No. 2:05CV189-PS-PRC, 2005 WL 2240036, at*11 (N.D. Ind. Sept. 13, 2005) (refusing to extend Rule 1.7(a) to a law firm soliciting city employees to bring civil rights lawsuits against the city while the firm represented the city because Rule 1.7(a) contemplates the concurrent conflicting representation of two clients); Guillen v. City of Chicago, 956 F. Supp. 1416, 1426 (N.D. Ill. 1997) (listing cases for the proposition that "directly adverse" conflicts must be direct and concrete; the mere possibility of, or potential for, conflict is insufficient); In re James, 679 S.E.2d 702, 709 (W. Va. 2009) (concluding that Rule 1.7 prohibition on direct adversity conflicts does not apply to a situation involving one current client and one potential client). 
CenTra, Inc. v. Estrin ${ }^{68}$ is a direct adversity conflict case with an environmental law flavor. It involved the Ambassador Bridge, which spans the Detroit River and connects Detroit, Michigan, with Windsor, Ontario. ${ }^{69}$ Two CenTra subsidiaries, the Detroit International Bridge Co. (DIBC) and its subsidiary, the Canadian Transit Co. (CTC), own and operate the bridge. ${ }^{70}$ Dan Stamper was the president of DIBC and CTC. ${ }^{71}$

For over twenty years, CenTra was represented by one of Canada's leading law firms, Gowling Lafleur Henderson, LLP (Gowlings). ${ }^{72}$ During that same time, David Estrin, a partner in Gowlings's Toronto office, periodically represented other clients in matters adverse to CenTra with Stamper's knowledge and, apparently, with CenTra's implied consent. $^{73}$ In 2002, Estrin began representing the city of Windsor concerning the heavy traffic over the Ambassador Bridge. ${ }^{74}$ Although Estrin's representation as initially scoped involved the bridge, it was not adverse to CenTra or its subsidiaries. ${ }^{75}$ Things turned adversarial, however, in the summer of 2004 when (1) CTC applied to Windsor for site plan approval to add more toll booths on the bridge and to expand the bridge deck; and (2) CTC applied to the U.S. Coast Guard to "twin" the Ambassador Bridge, that is, to build a second bridge beside the original. ${ }^{76}$ CTC's plan to twin the bridge became known as the "Bridge Plan."77 Estrin soon began representing Windsor in opposing CTC's site plan and, in 2006, began representing Windsor in resisting the Bridge Plan. In September 2006, for example, Estrin wrote to the Coast Guard to oppose the Bridge Plan. ${ }^{78}$ As a result, the Coast Guard demanded an environmental assessment from CenTra that cost the company around $\$ 800,000 .^{79}$

In the meantime, CenTra retained Gowlings to assist it in preparing a \$700-800 million bond offering to finance the Bridge Plan. ${ }^{80}$ "Thus, by September 2006, Gowlings was simultaneously helping CenTra procure

\footnotetext{
68. 538 F.3d 402 (6th Cir. 2008).

69. Id. at $405-06$.

70. Id. at 406 .

71. Id.

72. Id.

73. Id.

74. Id.

75. Id.

76. Id.

77. Id.

78. Id. at 407.

79. Id.

80. Id.
} 
funding for the bridge expansion and assisting Windsor in trying to halt the bridge expansion." 81 No one at Gowlings or CenTra initially spotted the conflict, nor could anyone decipher how it came to be. ${ }^{82}$

CenTra eventually figured out that Gowlings was both friend and foe and sued the firm in a Michigan federal court for breach of contract, breach of fiduciary duty, and legal malpractice, all grounded in Gowlings's concurrent conflict of interest. ${ }^{83}$ The district court awarded Gowlings summary judgment, holding that CenTra had impliedly consented to any conflict of interest. ${ }^{84}$ The district court found that CenTra had impliedly consented based on Stamper's repeated engagement of Gowlings over the years to represent CenTra and its subsidiaries despite knowing that Gowlings had represented parties (including Windsor) that were adverse to CenTra in matters where CenTra was represented by other law firms. ${ }^{85}$ CenTra appealed the district court's decision to the Sixth Circuit. ${ }^{86}$

In reviewing the district court's grant of summary judgment, the Sixth Circuit observed that " $[\mathrm{t}]$ here are some conflicts of interest to which a client may not consent." 87 Unfortunately, in concluding that CenTra had impliedly consented to Gowlings's conflict of interest, the district court "ignored the question of whether Gowlings's simultaneous and adverse representation of CenTra and Windsor was in fact a conflict to which CenTra could consent." 88 The CenTra court held that there was a genuine issue of material fact as to whether Gowlings's conflict of interest regarding the Bridge Plan was consentable. ${ }^{89}$ As the court explained:

The Michigan Rules of Professional Conduct state that "[a] lawyer shall not represent a client if the representation of that client will be directly adverse to another client, unless: (1) the lawyer reasonably believes the representation will not adversely affect the relationship with the other client; and (2) each client consents after consultation." . . . This rule has particular salience when the attorney is representing both sides in the same conflict ....

81. Id.

82. See id. at 407-08 ("Both CenTra and Gowlings claimed ignorance as to this conflict of interest. According to Stamper: 'I was not aware that Gowlings was representing Windsor in opposition to the Second Span until September, 2006, when I saw Mr. Estrin's letter to the U.S. Coast Guard ... opposing the Second Span.' . . Estrin claimed to be even more clueless[.]" (citations to the record omitted)).

83. Id. at 408 .

84. Id. at 405,409 .

85. Id. at 409 .

86. Id.

87. Id. at 412 .

88. Id.

89. Id. 
That CenTra and Windsor are not directly adverse ... in a lawsuit is not determinative. Without a doubt, the ethical concerns would be greater if Gowlings were representing both sides in the same lawsuit.... However ... representing both sides of a matter that is not in litigation can make a conflict of interest nonconsentable if the differences between the wrangling parties are large enough. ...

The district court broadly stated that a client may consent to a conflict of interest; however, it is not true that all conflicts are consentable. Whether a conflict is consentable depends upon the facts of the case. According to the commentary to Michigan's Rule 1.7, a conflict is nonconsentable "when a disinterested lawyer would conclude that the client should not agree to the representation under the circumstances." Given the evidence presented at the summary-judgment stage of this case, we hold that there is a genuine issue of material fact as to whether Gowlings reasonably believed that the conflict would not adversely affect its relationship with its clients, and whether a disinterested lawyer would conclude that CenTra should agree to the representation. CenTra submitted to the district court a declaration from an expert who stated that "I simply do not see how a law firm can offer sound professional service simultaneously to a client it is helping to build a bridge and to a client it is helping to block or delay construction of the bridge. This is not even a close question." Thus, CenTra presented a genuine issue of material fact as to whether this conflict was one to which it was capable of giving consent, and the district court's grant of summary judgment was erroneous. ${ }^{90}$

Even if the conflict was consentable, there was a genuine issue of material fact as to whether Gowlings adequately informed CenTra of the conflict to achieve consent. ${ }^{91}$ The Sixth Circuit concluded that CenTra's knowledge of Estrin's prior representations of parties adverse to CenTra in unrelated matters did not adequately inform CenTra about the nature of Gowlings's conflict of interest regarding the Bridge Plan. ${ }^{92}$ As other courts had previously clarified, a lawyer cannot leave a client "to infer the full nature of a conflict from only bits and pieces of actual or constructive knowledge." 93

Gowlings argued that the district court properly focused on CenTra's awareness of a conflict of interest rather than flagging CenTra's knowledge of Gowlings's opposition to the Bridge Plan. ${ }^{94}$ "In other words, Gowlings contend[ed] that knowledge of earlier conflicts can constitute knowledge sufficient to consent to a different, subsequent

90. Id. at 413-14 (internal citations and footnotes omitted).

91. Id. at 414 .

92. Id. at 415 .

93. Id.

94. Id. at 416 . 
conflict."95 The CenTra court disagreed, reasoning that "the 'informed' part of informed consent is tied to knowledge of the conflict in question, not different conflicts." 96 Indeed, if the general information that CenTra had regarding prior, unrelated conflicts of interest involving Gowlings in general and Estrin in particular gave rise to informed consent in this case, "then the client would bear the burden of identifying and understanding the full scope of any conflict of interest." 97 Of course, rules of professional conduct hold lawyers - not clients - responsible for recognizing conflicts of interest, and for protecting clients from their effects. ${ }^{98}$ As the court summarized the situation:

A client's knowledge that his law firm has, on previous occasions, represented parties that opposed the client in different matters does not provide an adequate foundation for informed consent with respect to a current simultaneous representation of two adverse clients with opposing interests in a specific dispute. Gowlings does not claim that it provided to CenTra more specific information regarding the current conflict on which informed consent could have been based, because Gowlings itself admits that it was not aware until 2006 of the conflict with respect to the Bridge Plan. It is, therefore, apparent that CenTra has at least established a genuine issue of material fact as to whether Gowlings fulfilled its obligation to inform CenTra of the full nature of the conflict arising from Gowlings's simultaneous and adverse representation of CenTra and Windsor with regard to the Bridge Plan. ${ }^{99}$

Digging in, Gowlings contended that CenTra's continued retention of the firm after learning of prior, unrelated conflicts of interest counted as implied consent to the firm's representation of Windsor regarding the Bridge Plan. ${ }^{100}$ As the court had already noted, however, client consent "must be determined on a conflict-by-conflict basis."101 Although CenTra's repeated use of Gowlings in years prior to Windsor and CenTra butting heads may have constituted consent to conflicts of interest arising during that time, it could not constitute consent to a prospective conflict unknown to CenTra. ${ }^{102}$ Plus, to prove implied consent under Michigan law, the lawyer must show that the client knew of the particular conflict. ${ }^{103}$

\footnotetext{
95. Id.

96. Id.

97. Id. at 417 .

98. Id.

99. Id.

100. Id. at 417-18.

101. Id. at 418 .

102. Id.

103. Id.
} 
This Gowlings had not done. ${ }^{104}$ Accordingly, Gowlings was not entitled to summary judgment. ${ }^{105}$

Weighing the evidence in the light most favorable to CenTra as the non-moving party, the Sixth Circuit determined that the district court erred in awarding Gowlings summary judgment. ${ }^{106}$ CenTra had "established genuine issues of material fact as to whether the conflict was consentable, whether CenTra was properly informed of the conflict, and whether CenTra's actions indicated implied consent." 107 The court therefore reversed the district court and remanded the case for further proceedings. ${ }^{108}$

CenTra involved direct adversity in related matters. Perhaps less obviously, a lawyer's representation of a client may be directly adverse to another current client even if the matters are unrelated. ${ }^{109}$ From lawyers' standpoint, the lack of relation between the concurrent matters is no defense to a direct adversity conflict, ${ }^{110}$ although it may well be relevant to whether the client may consent to the conflict, ${ }^{111}$ or whether the law firm's disqualification is required. ${ }^{112}$ Nor may a lawyer overcome a direct adversity conflict on the basis that the client to whom the lawyer is directly

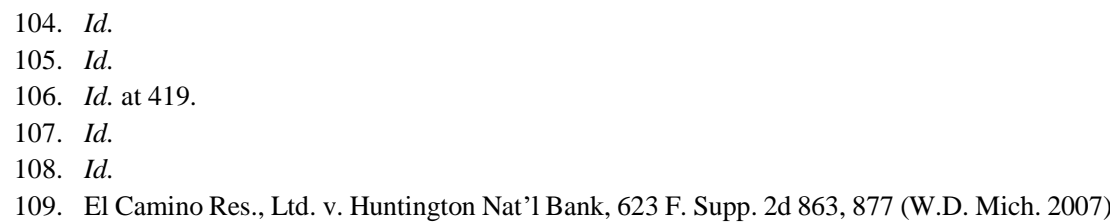
(quoting Fla. Ins. Guar. Ass'n., Inc. v. Carey Canada, Inc., 749 F. Supp. 255, 259 (S.D. Fla. 1990)); MOdEl Rules OF PROF'L CONDUCT r. 1.7 cmt. 6 (AM. BAR Ass'N 2019) (“Thus, absent consent, a lawyer may not act as an advocate in one matter against a person the lawyer represents in some other matter, even when the matters are wholly unrelated."). See, e.g., Ill. State Bar Ass'n Prof'l Conduct, Adv. Op. 17-03, at 2-3 (2017), https://www.isba.org/sites/default/files/ethicsopinions/17-03.pdf [http s://perma.cc/X935-BNY5] (explaining that a lawyer could not represent a husband and wife in selling their house where the lawyer was representing the husband in a contemplated divorce from his wife although no petition for dissolution had been filed).

110. See, e.g., GSI Commerce Sols., Inc. v. BabyCenter, L.L.C., 618 F.3d 204, 210 (2d Cir. 2010) ("In this respect, it will not suffice to show that the two matters upon which an attorney represents existing clients are unrelated."); Reed v. Hoosier Health Sys., 825 N.E.2d 408, 412 (Ind. Ct. App. 2005) ("Reed contends IRPC 1.7(a)'s use of 'directly' indicates there must be some relation between the suits before disqualification is proper. . . . However, IRPC 1.7(a)'s use of 'directly' refers to the adverse effect to the client not the attorney-client relationship." (citations to the record omitted)).

111. See, e.g., Ill. State Bar Ass'n Prof'l Conduct, Adv. Op. 99-01, at 2 (1999), https://www.isba .org/sites/default/files/ethicsopinions/99-01.pdf [https://perma.cc/2LP3-VHCB] (ruling that a lawyer could not represent a husband in a divorce action while representing the wife in a custody proceeding because the matters were related in addition to the representations being directly adverse).

112. See, e.g., Prudential Ins. Co. of Am. v. Anodyne, Inc., 365 F. Supp. 2d 1232, 1237-40 (S.D. Fla. 2005) (refusing to disqualify a law firm in a CERCLA cost recovery action or allow it to withdraw based on a direct adversity conflict where the firm's representation of the movant in unrelated matters would not prejudice the movant in the environmental case). 
adverse is represented by another lawyer in the matter. ${ }^{113}$ In sum, if a lawyer represents one client against a client that the lawyer (or the lawyer's firm) simultaneously represents in an entirely unrelated matter, a direct adversity conflict exists. ${ }^{114}$

\section{B. Material Limitation Conflicts}

The second type of concurrent conflicts of interest - a material limitation conflict - arises when there is a significant risk that a lawyer's representation of a client will be materially limited by the lawyer's responsibilities to someone else, or by the lawyer's own interests. ${ }^{115}$ Material limitation conflicts are more subtle than direct adversity conflicts and require a lawyer to evaluate whether "there is a significant risk that a lawyer's ability to consider, recommend or carry out an appropriate course of action for the client will be materially limited as a result of the lawyer's other responsibilities or interests." 116 Normally, there is some pull on the lawyer's judgment or something about the situation that prompts the lawyer to reflect on the propriety of accepting both representations. ${ }^{117}$

Material limitation conflicts require careful study of the facts and circumstances of each matter. ${ }^{118}$ Indeed, by their very nature, the concepts of materiality and significant risk are case-specific. In many instances, however, the material limitation on the lawyer's representation will be "immediate, actual, and apparent." 119

113. Quinn v. Anvil Corp., No. C08-0182RSL, 2008 WL 11344647, at *2 (W.D. Wash. Aug. 27, 2008).

114. See, e.g., Prudential Ins. Co. of Am., 365 F. Supp. 2d at 1236 (acknowledging the direct adversity conflict).

115. Model Rules of Prof'L Conduct r. 1.7(a)(2) (AM. Bar Ass'N 2019); Restatement (THIRD) OF THE LAW GOVERNING LAWYERS $§ 121$ (AM. LAW INST. 2000).

116. Model Rules of Prof'L CONDUCT r. 1.7 cmt. 8 (AM. BAR AsS'N 2019).

117. See Iowa Sup. Ct. Att'y Disciplinary Bd. v. Willey, 889 N.W.2d 647, 653-54 (Iowa 2017) ("The key questions a lawyer must ask are whether it is likely a difference of interests will occur between the clients and, if so, whether that difference in interests will interfere with the lawyer's ability to offer independent, professional judgment to each client." (citation omitted)); Commonwealth v. Cousin, 88 N.E.3d 822, 834-38 (Mass. 2018) (discussing situations that may present Rule 1.7(a)(2) conflicts); State ex rel. Union Planters Bank, N.A. v. Kendrick, 142 S.W.3d 729, 736 (Mo. 2004) (noting that this kind of conflict of interest "in effect forecloses alternatives that would otherwise be available to the client").

118. See, e.g., Georgine v. Airchem Prods., Inc., 157 F.R.D. 246, $326-30$ (E.D. Pa. 1994) (concluding that class counsel did not have a material limitation conflict), vacated on other grounds, 83 F.3d 610 (3d Cir. 1996); Saline Mem'l Hosp. v. Berry, 906 S.W.2d 297, 299-300 (Ark. 1995) (finding no material limitation conflict); Att'y Grievance Comm'n of Md. v. Woolery, 198 A.3d 835, 851-52 (Md. 2018) (determining that the lawyer had a material limitation conflict of interest).

119. RestateMENT (THIRD) OF THE LAW GOVERNING LAWYERS $§ 121 \mathrm{cmt}$. c(iii) (AM. LAW INST. 2000). 
Perhaps the more difficult determination is whether the risk "is significant and plausible, even if it is not certain or even probable that it will occur." 120 The mere suggestion of a potential conflict of interest, or a mere possibility of divergent interests, is insufficient. ${ }^{121}$ The conflict must be clear and specific; it cannot rest on speculation. ${ }^{122}$ As the Iowa Supreme Court explained in Bottoms v. Stapleton, ${ }^{123}$ "only an actual conflict of interest, as defined in [Rule 1.7(a)(2)], will justify [a lawyer's] disqualification." 124 Bottoms reflects the majority rule. ${ }^{125}$

\section{Conflicts in Superfund Litigation}

Superfund litigation may give rise to either direct adversity or material limitation conflicts of interest. ${ }^{126}$ To understand related conflicts, it is first necessary to understand some rudimentary aspects of CERCLA.

Rather than framing a regulatory scheme, CERCLA establishes financial responsibility for cleaning up hazardous waste "facilities" or

120. Id.

121. In re Penning, 930 A.2d 144, 155-56 (D.C. 2007); Frank Settelmeyer \& Sons, Inc. v. Smith \& Harmer, Ltd., 197 P.3d 1051, 1059 n.33 (Nev. 2008); RestateMENT (THIRD) OF THE LAW GOVERNING LAWYERS § $121 \mathrm{cmt}$. c(iii) (AM. LAW INST. 2000).

122. See, e.g., D.C. Bar Legal Ethics Comm., Op. 356 (2010), https://www.dcbar.org/barresources/legal-ethics/opinions/opinion356.cfm [https://perma.cc/5EV3-FPE6] (stating that a lawyer in a specialized industry may represent Client $A$ in its attempt to acquire Company $X$, even though the lawyer's experience suggests that it is likely other companies in the same industry, including one of her clients, will also bid to acquire Company $X$ and oppose Client $A$ 's bid because the lawyer cannot identify the nature of the conflict or the specific clients that might be affected).

123. 706 N.W.2d 411 (Iowa 2005).

124. Id. at 417 (referring to Iowa CT. R. 32:1.7). Of course, "if there is a significant risk that representation of one client will materially limit the representation of another client, a conflict of interest actually exists; it is not merely potential." Id.

125. See, e.g., Shaffer v. Farm Fresh, Inc., 966 F.2d 142, 145 (4th Cir. 1992) (finding that disqualification "may not be rested on mere speculation that a chain of events whose occurrence theoretically could lead counsel to act counter to his client's interests might in fact occur" (citation omitted)); P\&L Dev. LLC v. Bionpharma Inc., No. 1:17CV1154, 2019 WL 357351, at *4 (M.D.N.C. Jan. 29, 2019) ("Disqualification is a serious matter which cannot be based on imagined scenarios of conflict." (quoting Plant Genetic Sys., N.V. v. Ciba Seeds, 933 F. Supp. 514, 517 (M.D.N.C. 1996)); Guillen v. City of Chicago, 956 F. Supp. 1416, 1422 (N.D. Ill. 1997) (stating that a lawyer should not be disqualified "unless there is a substantial basis for believing that actual, rather than merely potential, conflicts of interest are afoot"); Frank Settelmeyer \& Sons, Inc., 197 P.3d at 1059 n.33 (adopting the Bottoms court's position).

126. Although the following discussion focuses on Superfund litigation initiated by the EPA, private parties may also pursue cost recovery actions under CERCLA. See Comprehensive Environmental Response, Compensation, and Liability Act, 42 U.S.C. § 9607(a)(4)(B) (2012) (allowing private cost recovery actions); Jeffrey M. Gaba, The Private Causes of Action Under CERCLA: Navigating the Intersection of Sections 107(A) and 113(F), 5 MICH. J. ENVTL. \& ADMIN. L. 117, 126 (2015) (stating that 42 U.S.C. $\$ 9607(a)(4)(B)$ allows private parties to recover their response costs). 
sites. $^{127}$ The EPA has the power to undertake the cleanup of hazardous waste sites. ${ }^{128}$ To bestow the government with the resources to fulfill this responsibility, CERCLA created the federal Hazardous Substances Trust Fund, better known as the "Superfund," to pay for government cleanup efforts. ${ }^{129}$ But more importantly for present purposes, CERCLA also empowers the EPA to recover "all costs of removal or remedial action" it incurs in remediating a hazardous waste site from potentially responsible parties - again, PRPs. ${ }^{130}$ Four categories of PRPs may be jointly and severally liable for the cost of cleaning up contaminated property: (1) the owner and operator of the site; ${ }^{131}$ (2) former owners and operators of the site; ${ }^{132}$ (3) generators, meaning "any person who by contract, agreement, or otherwise arranged for disposal or treatment, or arranged with a transporter for transport for disposal or treatment, of hazardous substances" at the site, ${ }^{133}$ and (4) transporters, meaning "any person who accepts or accepted any hazardous substances for transport to disposal or treatment facilities ... or sites selected by such person, from which there 2013)

127. Philip WeInBERg \& KeVIn A. ReILly, Understanding ENVIRONMENTAl LAW 282 (3d ed.

128. 42 U.S.C. $\$ 9604$ (a) (2012).

129. Gaba, supra note 126 , at 123 n.23.

130. 42 U.S.C. $\$ 9607(a)(4)(A)$ (2012). The Sixth Circuit outlined CERCLA's complicated web of cost-shifting provisions in Hobart Corp. v. Waste Management of Ohio, Inc., 758 F.3d 757 (6th Cir. 2014):

The government may clean up the site itself under CERCLA $\S 104,42$ U.S.C. $§ 9604$; the government may compel a [PRP] to clean up the site through an action under CERCLA $\S$ 106, 42 U.S.C. § 9606; or the government may enter into an agreement with a PRP under CERCLA $\S 122,42$ U.S.C. $\S 9622$, that requires the PRP to clean up the site. If the government removes the waste and remediates the site, it may recover its response costs from PRPs under $§ 107(a)(4)$; if a private party actually incurs response costs rehabilitating the site, it may partially recover those response costs under $\S 107(\mathrm{a})(4)(\mathrm{B})$. In turn, any party sued under $\S 106$ or $\S 107$, by the government or a private party, may seek contribution from other PRPs under $\S 113(\mathrm{f})(1)$, so that the recovery costs can be distributed in an equitable fashion.

Another option for the government is to clean up the site itself and enter into a settlement agreement with PRPs to cover the government's response costs. In this scenario, [under $\S$ 113(f)(3)(B)] "[a] person who has resolved its liability to the United States . . . for some or all of a response action or for some or all of the costs of such action in an administrative or judicially approved settlement may seek contribution from any [PRP] who is not a party to [the] settlement." In exchange for resolving its liability, [under § 113(f)(2)] the settling PRP "shall not be liable for claims for contribution regarding matters addressed in the settlement."

Id. at 762-63 (internal citations and footnote omitted).

131. 42 U.S.C. $\$ 9607(a)(1)(2012)$.

132. Id. $\S 9607(\mathrm{a})(2)$.

133. Id. § 9607(a)(3). In other words, a generator "is the party with whom the hazardous waste originated.” WEINBERG \& REILLY, supra note 127, at 288. 
is a release, or threatened release" of hazardous substances for which cleanup costs must be incurred. ${ }^{134}$

PRPs may be further classified as de minimis or major. A party is typically classified as a de minimis PRP either because the amount of hazardous waste it contributed to the site or the toxicity of the waste it contributed to the site are slight in comparison to other hazardous substances at the site. ${ }^{135}$ The EPA calculates de minimis settlements using a fairly standard formula, such that de minimis parties' liability is generally easy to determine. ${ }^{136}$ Allocation disputes among de minimis PRPs are rare. ${ }^{137}$ "Given the breadth and scope of [CERCLA] liability, Superfund cases frequently involve numerous de minimis generator or transporter parties." 138

PRPs may sue one another for contribution. ${ }^{139}$ CERCLA contribution actions are governed by federal law. ${ }^{140}$ In such cases, a district court may allocate response costs among responsible parties according to appropriate equitable factors. ${ }^{141}$ A lawyer whose PRP clients wanted to pursue contribution claims against each other in an adversary proceeding would face a conflict of interest. ${ }^{142}$ In some instances, parties' agreement not to pursue contribution claims may eliminate any concurrent conflict of interest. $^{143}$

The sheer number of PRPs tied to any Superfund site means that any law firm with an environmental law practice may see multiple clients identified as PRPs or may find multiple PRPs approaching its

\footnotetext{
134. $§ 9607(a)(4)$.

135. Id.; § 9622(g)(1)(A).

136. Kenefick et al., supra note 4 , at 742-43.

137. Id.

138. Id. at $740-41$.

139. $§ 9613(\mathrm{f})$.

140. Id.

141. Id. Courts allocating response costs typically apply the so-called "Gore factors," which are:

(1) the ability of the parties to demonstrate that their contribution to a discharge, release, or disposal of hazardous waste can be distinguished; (2) the amount of the hazardous waste involved; (3) the degree of toxicity of the hazardous waste involved; (4) the degree of involvement by the parties in the generation, transportation, treatment, storage, or disposal of the hazardous waste; (5) the degree of care exercised by the parties with respect to the hazardous waste concerned, taking into account the characteristics of such hazardous waste; and (6) the degree of cooperation by the parties with Federal, State, or local officials to prevent harm to the public health or the environment.

TDY Holdings, LLC v. United States, 885 F.3d 1142, 1146 n.1 (9th Cir. 2018) (quoting Kerr-McGee Chem. Corp. v. Lefton Iron \& Metal Co., 14 F.3d 321, 326 n.4 (7th Cir. 1994)).

142. Model Rules of Prof'L CONdUCT r. 1.7(a)(1) (AM. BAR Ass'N 2019).

143. See Va. State Bar Legal Ethics Comm., Op. 1508 (1993), https://www.vsb.org/docs/LEO/ 1508.pdf [https://perma.cc/4GHG-SYPM] (applying then-existing Virginia disciplinary rules).
} 
environmental lawyers for representation. In fact, a hazardous waste site may have hundreds or thousands of PRPs. ${ }^{144}$ Naturally, as the Michigan State Bar Legal Ethics Committee observed:

Having so many parties identified as PRPs often presents those parties with problems in obtaining specialized representation at a reasonable cost. It would generally be impracticable, if not impossible, for each party to have separate counsel. Transaction costs for a party can be minimized through common representation. Most clients further prefer, whenever possible, to stay with counsel familiar with their business and operations. If any given firm may represent only one PRP at any given site, most clients will be unable to obtain specialized representation at a reasonable cost, will be forced to utilize unfamiliar counsel, and there are serious questions raised regarding the sufficient availability of competent counsel experienced in Superfund matters. ${ }^{145}$

CERCLA's joint and several liability scheme further makes every PRP at least potentially adverse to every other PRP in some circumstances. ${ }^{146}$ As the Michigan State Bar observed in a rare ethics opinion on this subject:

PRPs may initially challenge other PRP designations as de minimis vs. major. Owners and generators are almost always antagonistic on issues of allocation. Major and de minimis PRPs may argue over the appropriate levels of contribution by the de minimis PRPs. PRPs may challenge the accuracy and/or completeness of another PRP's Section 104(e) disclosure [concerning the identification, nature, and quantity of materials which have been or are generated, treated, stored, or disposed of at a facility or transported to facility]. Major PRPs may argue over allocation of clean up and other costs. All of these scenarios are possible in any given case. ${ }^{14}$

As challenging as Superfund cases may be from a conflict of interest standpoint, it is possible to frame a few general rules. ${ }^{148}$ Lawyers must appreciate, however, that cases are fact-specific and that general rules have exceptions. Furthermore, the existence or lack of a conflict of interest may depend on the scope of the lawyer's representation. ${ }^{149}$

144. Stein \& Geht, supra note 5, at 731; Kenefick et al., supra note 4, at 726.

145. Mich. State Bar, Ethics Op. R-16 (1993), https://www.michbar.org/opinions/ethics/number ed_opinions/R-016 [https://perma.cc/CL6J-4RF7] [hereinafter Mich. Ethics Op. R-16].

146. Kenefick et al., supra note 4, at 726.

147. Mich. Ethics Op. R-16, supra note 145, at 2.

148. This article does not attempt to address all conflicts of interest that may arise in CERCLA litigation.

149. See generally MOdEl Rules of PROF'L CONDUCT r. 1.2(c) (AM. BAR Ass'N 2019) (allowing limited scope representations under certain conditions). 


\section{Representation of Multiple De Minimis PRPs}

A lawyer or law firm should be able to represent multiple de minimis PRPs in the same de minimis group without having to obtain consent from each client. ${ }^{150}$ If the lawyer is negotiating with the EPA for a lower overall share of liability for the clients' category of PRP, the parties' interests are aligned. If the lawyer is advising the clients whether to settle with the EPA, the parameters for liability are clearly defined and the same for all. ${ }^{151}$ In most cases, there is little chance of conflicts of interest dividing PRPs in the same de minimis group. ${ }^{152}$ If, however, the criteria for establishing de minimis status have not been determined at the time the law firm or lawyer is retained, the likelihood of a conflict developing increases because different PRPs may hold competing views on the criteria for de minimis classification. ${ }^{153}$ Then, depending on the facts, joint representation may be impossible or may require the affected clients' informed consent. ${ }^{154}$

\section{Representation of De Minimis and Major PRPs}

Superfund cases are generally divided into two phases: remedy selection first and allocation of responsibility second. Thus, a law firm may for years represent multiple parties who are aligned in interest in the selection of remedies but who become adverse in the allocation process. A law firm may navigate this situation by limiting the scope of its representation so that it will not represent one client against another in any allocation dispute. ${ }^{155}$ As this discussion suggests, however, a lawyer or law firm generally will be unable to represent a de minimis and a major PRP in the same case if the representation involves allocation issues. ${ }^{156}$ The same is true if a major PRP objects to the "formulation of the de minimis category" of PRPs or "want[s] to... limit the scope of the

150. Kenefick et al., supra note 4 , at 742

151. See Mich. Ethics Op. R-16, supra note 145, at 3 ("Given that de minimis PRPs in Superfund proceedings often settle according to a set multiplier (premium) of their volumetric contribution to the site, their interests are often aligned.").

152. Id.

153. Kenefick et al., supra note 4 , at 743 .

154. See id. at 743-44 (suggesting that this situation could create a consentable Rule 1.7(a)(2) conflict).

155. Model Rules of Prof'L CONDUCT r. 1.2(c) (AM. BAR Ass'N 2019). A client may always retain separate counsel to represent it in connection with any allocation issues or with respect to potential contribution claims against other PRPs.

156. Mich. Ethics Op. R-16, supra note 145, at 4. 
release[s]" that de minimis PRPs execute. ${ }^{157}$

On the other hand, if the lawyer or law firm represents either a de minimis or major PRP solely in unrelated matters and there are no allocation, categorization, or settlement issues in the CERCLA litigation, there may either be no material limitation conflict of interest or it may be possible to seek the clients' consent to the conflict. ${ }^{158}$ Or, the terms of a de minimis settlement may be such that a law firm's concurrent representation of a de minimis and a major PRP poses no conflict of interest. Naturally, all these situations are case- and fact-dependent. ${ }^{159}$

\section{Representing Multiple Major PRPs}

Lawyers who represent current or former owners or operators of hazardous waste sites generally will be unable to represent generators or transporters in the same matter when the allocation of remediation costs between these categories of PRPs is at issue because of the resulting direct adversity conflicts of interest. ${ }^{160}$ "Each class will try to minimize its liability while maximizing the liability of the other classes." ${ }^{61}$ For example:

Generators typically argue that the owners/operators should bear significant liability because of the way they handled waste at the facility. For example, generators may argue that the operators greatly contributed to remediation costs by causing material to be released into the environment. Conversely, the owners/operators will argue that they followed accepted standards and the high toxicity of the hazardous material supplied by the generators increased remediation costs. Additionally, the owners/operators may show that they took actions to address waste handling at the site properly. EPA may consider the value of these initiatives, the degree of cooperation with public officials, and compliance with various regulations to determine liability allocation. ${ }^{162}$

Direct adversity conflicts may also arise between owners and

157. Kenefick et al., supra note 4 , at 741 .

158. Id. at 741-42.

159. See id. ("Ethical considerations become more difficult when a law firm represents an owner/operator or a major generator or transporter in a CERCLA matter, yet also represents de minimis PRPs in non-CERCLA matters. . . For example, to benefit the major PRP client, the law firm may wish to contest the de minimis settlement terms generally, or target a specific party's de minimis status." (footnote omitted)); see also Mich. Ethics Op. R-16, supra note 145, at 4 (noting that a lawyer will likely be disqualified from representing an owner and a generator in the same matter absent a prior binding agreement on cost allocation).

160. Mich. Ethics Op. R-16, supra note 145, at 4; Kenefick et al., supra note 4, at 735.

161. Kenefick et al., supra note 4, at 735 (footnote omitted).

162. Id. at 736 (footnotes omitted). 
operators of hazardous waste sites if those entities or individuals are different. For example, an owner who leases a site to an operator will likely attempt to allocate most of the liability for cleaning up the site to the operator. ${ }^{163}$ By way of further example, a current owner may want to argue that the greatest share of liability should be assessed against the former owner, or vice versa. ${ }^{164}$ A single lawyer or law firm cannot represent both parties in either instance. ${ }^{165}$

Generators can find themselves adverse to one another. For example, generators may contest the nature or relative noxiousness of the waste that each contributed to a site. ${ }^{166}$ Although observers have suggested that the generators can waive a common lawyer's conflict of interest in this situation, ${ }^{167}$ whether a prudent lawyer should seek such consent may be a different story altogether depending on the facts. On the other hand, multiple generators may knowingly agree to set aside for a time their differences over their respective obligations in the belief that presenting a unified front against other parties is more advantageous. ${ }^{168}$ In such a case, a single lawyer or law firm could, with the generators' informed consent, represent them all. ${ }^{169}$ The lawyer or law firm could not, however, later argue for any allocation of liability or responsibility among them because the lawyer would then be preferring one client's interests over another's. ${ }^{170}$ Also, it might be possible for a law firm to represent multiple generators individually rather than as a group so long as the firm does not represent one generator against another in attempting to allocate liability. ${ }^{171}$

Finally, while transporters and generators may be aligned in some cases,${ }^{172}$ their interests can diverge when it comes to allocating cleanup

\footnotetext{
163. Id. at $736-37$.

164. Id. at 737 .

165. MOdEl RULES OF PROF'L CONDUCT r. 1.7(a) (AM. BAR ASS'N 2019).

166. Kenefick et al., supra note 4 , at 739 .

167. Id. at 739-40.

168. See, e.g., Acushnet Co. v. Coaters, Inc., 972 F. Supp. 41, 70 (D. Mass. 1997) (“[The plaintiffs] were free to forego pressing for judicial resolution of their conflicting interests and to agree that their common interest in presenting a unified position against $\mathrm{CDE}$ and other defendants ... so far outweighs their conflicting interests among themselves that they are better served by foregoing pursuit of conflicts and acting together.").

169. Id.

170. Id.

171. See generally Model Rules of Prof'L CONDUCt r. 1.2(c) (AM. BAR AsS'N 2019) (permitting limited scope representations under certain conditions).

172. See Kenefick et al., supra note 4, at 738 ("'A]t many Superfund sites, individual generators or transporters may share interests. This is especially true for smaller operations and entities. PRPs often distribute liability for the cleanup on a volumetric basis. Therefore, the generators and transporters will share an interest in reducing both the overall investigation and remediation costs, as well as the costs attributable to their particular PRP group." (footnotes omitted)).
} 
costs. Transporters may argue that generators should bear the greatest liability because they produced the hazardous substances, while generators should be expected to argue that transporters should be principally liable because they selected the disposal site. ${ }^{173}$ From a lawyer's standpoint, these opposing positions create a non-consentable conflict of interest. ${ }^{174}$

\section{Summary}

As previously noted more than once, conflicts of interest in Superfund cases tend to be case- and fact-specific. Consider, for example, the distinction between EPA cost recovery actions under 42 U.S.C. $\$ 9607$ and PRPs' contribution actions under 42 U.S.C. $\S 9613$. CERCLA gives EPA the right to remedy contamination at a hazardous waste site and then sue basically anyone involved with the site under $\S 9607$ to recover its costs. ${ }^{175}$ As the Seventh Circuit once explained the linkage between $\S 9607$ and $\S$ 9613 actions, "CERCLA imposes a 'pay-first, split-the-bill-later' regime. Any [party] meeting certain statutory criteria can be required to pay for the cleanup. Anyone who paid can then recover contribution from other responsible parties in accordance with that entity's equitable share of the costs." $" 176$

Defendants' liability in a cost recovery action under $\S 9607$ is clearly joint and several because a single PRP may be held accountable for the entire cost of remediation at a site despite the existence of other polluters. ${ }^{177}$ PRPs' relative degree of fault is simply irrelevant to the EPA or a private party plaintiff pursuing a cost recovery action under $\S 9607 .{ }^{178}$ In contribution actions, on the other hand, "parties seeking contribution bear the burden of demonstrating a right to apportionment, identifying the other contaminating parties and the extent of their involvement." ${ }^{179}$ In a contribution action under $\S 9613$, a PRP plaintiff is entitled to recover only that sum that will result in an equitable distribution of response costs. ${ }^{180}$

\footnotetext{
173. Id.

174. MOdEL RULES OF PROF'L CONDUCT r. 1.7(a) \& (b)(3) (AM. BAR ASS'N 2019).

175. 42 U.S.C. $\$ 9607$ (a) (2012).

176. NCR Corp. v. George A. Whiting Paper Co., 768 F.3d 682, 686 (7th Cir. 2014).

177. Niagara Mohawk Power Corp. v. Chevron U.S.A., Inc., 596 F.3d 112, 121 (2d Cir. 2010).

178. WEINBERG \& REILLY, supra note 127, at 298.

179. Id. at 303 (footnote omitted).

180. See Pa. Dep't of Envtl. Prot. v. Trainer Custom Chem., LLC, 906 F.3d 85, 92 (3d Cir. 2018) ("'[W]hen a PRP must bear 'more than its fair share' of cleanup costs resulting from a $\S 107$ cost recovery action, it can seek a more equitable distribution of those costs through a contribution action against other PRPs."); Trinity Indus. v. Greenlease Holding Co., 903 F.3d 333, 348 (3d Cir. 2018) ("While $\S 107$ (a) authorizes complete cost recovery under a joint and several liability theory, § 113(f) permits a party to seek contribution from other PRPs ....”); Whittaker Corp. v. United States, 825
} 
This difference between cost recovery and contribution actions matters for conflict of interest purposes because, depending on the facts and perhaps the court, a lawyer defending multiple PRPs may be able to defeat a contribution claim brought against one client without increasing other clients' monetary liability.

In addition, parties' interests may change over time depending on the then-current issues and phase of the case. For example, PRPs that are aligned in interest when trying to identify additional PRPs may see their interests diverge when it comes time to select a means of remediating the contamination at the site. Parties' interests also may shift during the allocation process, which may involve multiple phases, the staged resolution of disputed issues, and more. It is frequently possible for lawyers and law firms to navigate related conflicts by carefully defining the scope of their representation. Or, two parties may agree to postpone or sever the resolution of any issues on which they are adverse until all matters in which they have a common interest have been concluded, thereby permitting joint representation for the time being. ${ }^{181}$

Finally, on a policy level, Superfund cases create a quandary. They may involve hundreds or thousands of PRPs, ${ }^{182}$ many of whom have no dealings with each other, and most of whom coast along in groups for years as issues shake out. All these parties deserve access to capable lawyers versed in this highly specialized area of law. Yet the population of such lawyers is limited. ${ }^{183}$ The result is that lawyers and courts should approach conflicts of interest in Superfund cases pragmatically, keeping in mind that rules of professional conduct-including those governing conflicts of interest - are rules of reason. ${ }^{184}$ Recognizing that conflicts of interest cannot be based on speculation, ${ }^{185}$ theoretical forms of adversity that might someday develop should in many cases be discounted or at least temporarily disregarded when analyzing concurrent conflicts of interest. ${ }^{186}$ Fortunately, environmental lawyers and parties to Superfund cases appear

F.3d 1002, 1007 (9th Cir. 2016) ("A party uses contribution to get reimbursed for being made to pay more than its fair share to someone else ....").

181. See Patrick E. Donovan, Comment, Serving Multiple Masters: Confronting the Conflicting Interests that Arise in Superfund Disputes, 17 B.C. EnVTL. AfF. L. ReV. 371, 400-01 (1990) (explaining how this might work in a multiple representation of members of one class of PRPs).

182. Kenefick et al., supra note 4, at 725 .

183. See Donovan, supra note 181, at 401 ("The number of law firms that have the capability of handling complex environmental tort defenses is typically much smaller than the number of PRPs that may be involved in any one Superfund case." (footnote omitted)).

184. Model Rules of Prof'L ConduCt Scope II 14 (AM. BAR Ass'N 2019).

185. See supra notes 121-22 and accompanying text.

186. See generally Donovan, supra note 181, at 400 (discussing the need to balance the possibility that a conflict of interest will develop with the relative benefits of multiple representation). 
to be taking realistic approaches to conflicts as evidenced by the scarcity of related cases and ethics opinions.

\section{Obtaining Client Consent to a Conflict}

Once it is determined that a concurrent client conflict exists, the next question is whether the conflict may be cured by client consent. In other words, whether it is possible for the concurrent representations to proceed notwithstanding the lawyer's conflict of interest because the clients will waive the conflict. Again, not all conflicts are consentable or "waiveable." 187

A conflict of interest is consentable if three conditions are met. First, the lawyer must reasonably believe that she will be able to competently and diligently represent each affected client. ${ }^{188}$ In other words, the lawyer must believe that each client can consent to the representation. ${ }^{189}$ Second, the representation must not be "prohibited by law." 190 Third, the representation cannot "involve the assertion of a claim by one client against another client represented by the lawyer in the same litigation or other proceeding before a tribunal[.]"191 Unless these three requirements are satisfied, the lawyer should not even attempt to obtain the client's informed consent to the conflict, confirmed in writing, which is the final step necessary for the lawyer to proceed with the representation. ${ }^{192}$

\section{A Reasonable Belief of Competent and Diligent Representation}

For a conflict of interest to be consentable, Model Rule 1.7(b)(1) requires the lawyer to reasonably believe that she can competently and diligently represent each affected client. ${ }^{193}$ If the lawyer cannot clear this initial hurdle, client consent is impossible; indeed, the lawyer cannot even seek the client's consent. ${ }^{194}$ A surprising number of lawyers seem to glide

\footnotetext{
187. RoTUNDA \& DZIENKOWSKI, supra note 12 , at 368.

188. Model Rules of Prof'L CONDUCT r. 1.7(b)(1) (AM. BAR ASS'N 2019).

189. Johnson v. Clark Gin Serv., Inc., No. 15-3290, 2016 WL 7017267, at *11 (E.D. La. Dec. 1, 2016) ("When a lawyer represents more than one client ... the question of consentability must be resolved as to each client." (footnote omitted)); State ex rel. Horn v. Ray, 325 S.W.3d 500, 507 (Mo. Ct. App. 2010) ("The question of consentability must be resolved as to each client."); MODEL RULES OF PROF'L CONDUCT r. 1.7 cmt. 14 (AM. BAR ASS'N 2019) ("When the lawyer is representing more than one client, the question of consentability must be resolved as to each client.").

190. Model Rules of Prof’L CONDUCT r. 1.7(b)(2) (AM. BAR AsS’N 2019).

191. Id. r. 1.7(b)(3).

192. Id. r. 1.7(b)(4) (requiring "informed consent, confirmed in writing").

193. Id. r. 1.7(b)(1).

194. Carnegie Cos. v. Summit Props., Inc., 918 N.E.2d 1052, 1067 (Ohio Ct. App. 2009).
} 
past this requirement, blithely confident in their ability to ably represent their clients notwithstanding the clients' competing interests. ${ }^{195}$ This is no time or place for incaution, however. Model Rule 1.7(b)(1) imposes an objective standard. ${ }^{196}$ A lawyer's subjective, good faith belief that she can fulfill her professional obligations to the affected clients notwithstanding any competing interests or obligations is therefore immaterial. ${ }^{197}$

Under the objective standard, the "facts and circumstances that the lawyer knew or should have known at the time of undertaking or continuing a representation" are relevant, as opposed to what became known to the lawyer later or could not have been reasonably anticipated by the lawyer. ${ }^{198}$ Thus, a lawyer must familiarize herself with the facts underlying the proposed representation to determine whether she can competently and diligently represent each affected client. ${ }^{199}$

While lawyers must honestly assess the circumstances and make a reasonable judgment that competent and diligent representation is achievable, best practices dictate that they not make that determination in isolation. In short, when deciding whether to accept or continue a representation despite a concurrent conflict of interest, disinterested lawyers in the firm should participate in the Rule 1.7(b)(1) analysis.

195. See Vicki J. Wright, Modern Conflicts of Interest, in ETHICS AND ENVIRONMENTAL PRACTICE 47, 55 (Irma S. Russell \& Vicki J. Wright eds., 2017) ("With a little mental gymnastics and a self-serving paper trail, many attorneys will find a way to get around actual conflicts in order to take on a matter ...." (footnote omitted)).

196. People v. Mason, 938 P.2d 133, 136 (Colo. 1997); In re Stein, 177 P.3d 513, 519 (N.M. 2008); see Ferolito v. Vultaggio, 949 N.Y.S.2d 356, 363 (App. Div. 2012) (requiring that a "disinterested lawyer" believe that the conflicted lawyer can competently represent each client's interests); Ill. State Bar Ass'n Prof'l Conduct, Adv. Op. 09-02, at 4 (2009), https://www.isba.org/sites/default/files/ ethicsopinions/09-02.pdf [https://perma.cc/KZS8-36M4] (explaining that a "reasonable belief is an objective standard predicated on what a disinterested lawyer would conclude as to whether the adverse clients would agree to the dual representation").

197. In re Stein, 177 P.3d at 519. See, e.g., So v. Suchanek, 670 F.3d 1304, 1310-11 (D.C. Cir. 2012) (rejecting as irrelevant the lawyer's subjective belief that no conflict existed in his joint representation of a victim of a Ponzi scheme and the person who involved the victim in the scheme; rather, the analysis depended on whether an objective observer with the lawyer's knowledge of the circumstances would have reasonably doubted his ability to undertake the joint representation); Robertson v. Wittenmyer, 736 N.E.2d 804, 809 (Ind. Ct. App. 2000) (finding that the lawyer could not have reasonably believed that the representation of one client against another was permissible and affirming the trial court's disqualification order).

198. RESTATEMENT (THIRD) OF THE LAW GOVERNING LAWYERS $§ 121 \mathrm{cmt}$. c(iv) (AM. LAW INST. 2000).

199. Felix v. Balkin, 49 F. Supp. 2d 260, 270 (S.D.N.Y. 1999); Ariz. State Bar Ethics Comm., Op. 07-04 (2007), https://www.azbar.org/Ethics/EthicsOpinions/ViewEthicsOpinion?id=696 [https://per ma.cc/A6K6-UREQ]. 
2. Representations Prohibited by Law

Model Rule 1.7(b)(2) bars representations that are prohibited by law. ${ }^{200}$ Thus, if a court rule, a rule of professional conduct, a statute, or controlling case law forbids dual representation in the situation at hand, the issue of client consent is irrelevant because the representation may not proceed anyway. ${ }^{201}$

Environmental cases often involve government agencies. In some states, government agencies may not be permitted to consent to conflicts of interest. State ex rel. Morgan Stanley \& Co. v. MacQueen ${ }^{202}$ is an illustrative case.

MacQueen involved a lawsuit by the State of West Virginia against three financial institutions to recover investment losses sustained by the West Virginia Consolidated Fund. ${ }^{203}$ The West Virginia Attorney General appointed the law firm of Wolff Ardis to represent the State. ${ }^{204}$ Wolff Ardis also represented seven employees of the State Treasurer's office when they were noticed for deposition as non-party witnesses. ${ }^{205}$ The defendants argued that these concurrent representations created a conflict of interest because the State had alleged in its complaints that the Treasurer's office managed the Fund at all relevant times and that unnamed Treasurer's office staff members contributed to cause the subject losses. ${ }^{206}$ The defendants further reasoned that because the staff controlled the disputed transactions, the State could only prove its case if it first established that the staff members (including Wolff Ardis's clients) broke the law. ${ }^{207}$

The court determined that the State's allegations against the unnamed members of the Treasurer's office created a concurrent conflict of interest for Wolff Ardis sufficient to disqualify the firm. ${ }^{208}$ The State argued that Wolff Ardis should not be disqualified because the seven staff members

200. Model Rules of Prof'L CONDUCT r. 1.7(b)(2) (AM. BAR ASS’N 2019).

201. See, e.g., Brown v. Kelton, 380 S.W.3d 361, 366 (Ark. 2011) (holding that an Arkansas statute prohibited an insurance company from using in-house lawyers to defend its insureds); Baldasarre $\mathrm{v}$. Butler, 625 A.2d 458, 467 (N.J. 1993) (adopting a bright-line rule prohibiting lawyers from representing the buyer and seller in complex commercial real estate transactions even if both parties consent); IOWA RULES OF PROF'L CONDUCT r. 32:1.7(c) (2012) (barring the representation of both parties in a marriage dissolution).

202. 416 S.E.2d 55 (W. Va. 1992).

203. Id. at 56-57.

204. Id. at 57 .

205. Id.

206. Id.

207. Id. at 59 .

208. Id. at 59-60. 
to be deposed had waived any conflicts. ${ }^{209}$ The problem, however, was that the State also had to consent to Wolff Ardis's multiple representations, which was impossible under West Virginia law. ${ }^{210}$ The court so concluded based on its statement in an earlier case that "where the public interest is involved, an attorney may not represent conflicting interests even with the consent of all concerned." 211 This rule rests on the rationale that it is "essential that the public have absolute confidence in the integrity and impartiality of our system of justice." 212 In light of the obvious public interest inherent in the State's attempt to recoup its investment losses, the court explained, the State could not consent to "a dual representation which involve[d] such adversity of interests as to raise even the appearance of such impropriety." 213

Fortunately for the State, the MacQueen court concluded that Wolff Ardis could remain in the case if the State dropped all allegations concerning the unnamed staff members in the Treasurer's office. ${ }^{214}$ Plainly anxious to retain Wolff Ardis as its counsel, the State had previously offered to amend its complaints to delete those allegations. ${ }^{215}$

At least three courts have similarly held that governmental entities may not consent to conflicts of interest. ${ }^{216}$ New Jersey, which was one of the earliest states to take this position, now enforces its prohibition on public agency conflict waivers through New Jersey Rules of Professional Conduct 1.7(b)(1) $)^{217}$ and 1.9(d). ${ }^{218}$

The better view holds that government clients' ability to waive conflicts of interest should be evaluated under the customary rules governing conflicts. ${ }^{219}$ In other words, a government entity's ability to waive a conflict of interest should depend on the facts and circumstances

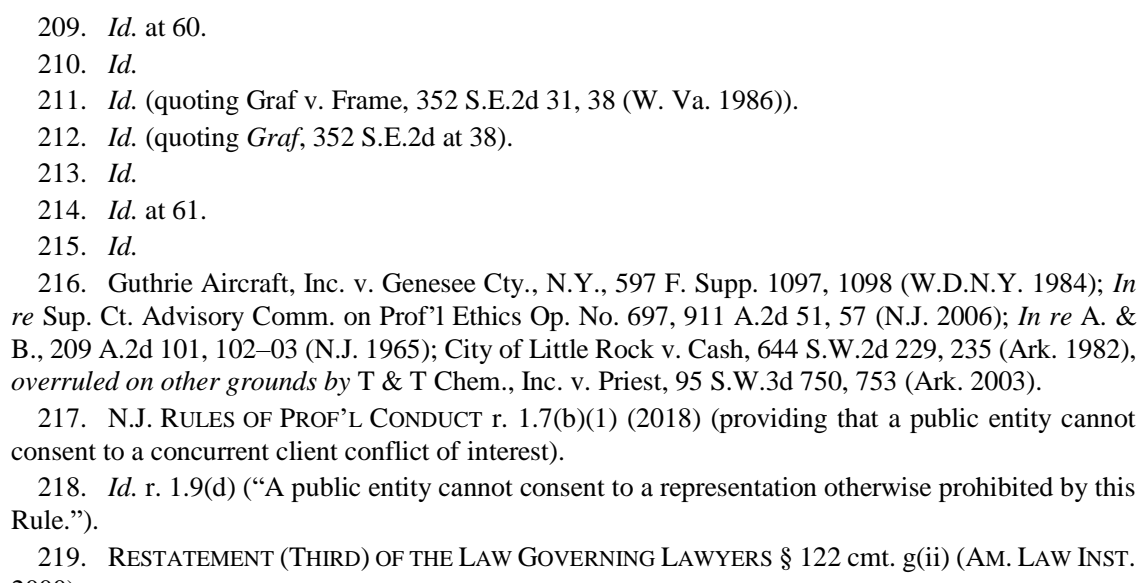

218. Id. r. 1.9(d) ("A public entity cannot consent to a representation otherwise prohibited by this Rule.").

219. Restatement (Third) Of the Law Governing LaWYers $§ 122 \mathrm{cmt}$. g(ii) (AM. Law InSt. 2000). 
of the case rather than on the entity's status. ${ }^{220}$ Consistent with this view, several bar ethics committees have reasoned that government agencies or entities may waive conflicts of interest in most circumstances, ${ }^{221}$ as have several courts. ${ }^{222}$

\section{Representing Opposite Sides in the Same Lawsuit}

Model Rule 1.7(b)(3) prohibits any representation that involves the "assertion of a claim by one client against another client represented by the lawyer in the same litigation or other proceeding before a tribunal."223 Indeed, a lawyer's or law firm's simultaneous representation of opposing parties in the same case is perhaps the most appalling conflict of interest conceivable. ${ }^{224}$ Client consent to such a conflict is ineffective. ${ }^{225}$

220. See, e.g., City of Cleveland v. Cleveland Elec. Illuminating Co., 440 F. Supp. 193, 204-05 (N.D. Ohio 1976) (concluding that the city could waive the conflict of interest).

221. See, e.g., ABA Comm. on Ethics \& Prof'l Responsibility, Formal Op. 97-405, at 4-5 (1997) (discussing general conflict of interest principles in the representation of government entities); D.C. Bar Legal Ethics Comm., Op. 268 (1996), https://www.dcbar.org/bar-resources/legal-ethics/op inions/opinion268.cfm [https://perma.cc/3MQR-B7GX ] (explaining the conflicts of interest with city governments are consentable); Ill. State Bar Ass'n Prof'l Conduct, Adv. Op. 12-12, at 4 (2012), https://www.isba.org/sites/default/files/ethicsopinions/12-12_0.pdf [https://perma.cc/SF2F-JVXY] (noting that "Illinois law permits public entities to consent to [their lawyers'] conflicts of interest"); N.Y. State Bar Ass'n Comm. on Prof'l Ethics, Op. 629, at 3 (1992), https://www.nysba.org/WorkArea /DownloadAsset.aspx?id=7371 [https://perma.cc/FG6R-MHWD] (concluding that "where a lawyer is faced with a conflict of interest, and one of the affected parties is a governmental entity, the lawyer may accept or continue the representation with the entity's consent," provided that the lawyer meets certain basic ethical obligations).

222. See, e.g., City of Cleveland, 440 F. Supp. at 205 (concluding that the city could waive the conflict of interest); Miller v. Norfolk \& W. Ry., 538 N.E.2d 1293, 1295-97 (Ill. App. Ct. 1989) (reasoning that a public entity may waive conflicts of interest); State ex rel. Nixon v. Am. Tobacco Co., 34 S.W.3d 122, 135-36 (Mo. 2000) (holding that the Missouri Attorney General was empowered to waive an alleged conflict of interest involving private lawyers handling tobacco litigation for the state).

223. Model Rules of PROF'L CONDUCT r. 1.7(b)(3) (AM. BAR ASS'N 2019).

224. See Synergy Tech \& Design, Inc. v. Terry, No. C 06-02073 JSW, 2007 WL 1288464, at *7 (N.D. Cal. May 2, 2007) (quoting Flatt v. Superior Court, 885 P.2d 950, 954 (Cal. 1994)); see also Jedwabny v. Phila. Transp. Co., 135 A.2d 252, 254 (Pa. 1957) ("No one could conscionably contend that the same attorney may represent both the plaintiff and defendant in an adversary action."); Vinson v. Vinson, 588 S.E.2d 392, 396, 398-99 (Va. Ct. App. 2003) (noting the trial court's observation that the lawyer's representation of both the husband and wife in a divorce was an outrageous conflict of interest and upholding the trial court's sanctions award).

225. See Model Rules of Prof'L Conduct r. 1.7 cmt. 23 (AM. BAR Ass'N 2019) ("Paragraph (b)(3) prohibits representation of opposing parties in litigation, regardless of the clients' consent." (emphasis added)). See, e.g., Nunez v. Lovell, Civ. No. 2005-7, 2008 WL 4525835, at *3-7 (D.V.I. Oct. 3, 2008) (disqualifying a lawyer who represented the plaintiffs and a defendant in the same case despite the clients' consent to the conflict). 
4. Obtaining the Clients' Informed Consent, Confirmed in Writing

Finally, if a lawyer has met the requirements of Model Rules 1.7(b)(1)-(3), she may avoid a concurrent client conflict of interest by obtaining the affected clients' informed consent to the conflict and confirming it in writing. ${ }^{226}$ A client's mere knowledge of a conflict is not sufficient for informed consent. Rather, informed consent requires a client's agreement "to a proposed course of conduct after the lawyer has communicated adequate information and explanation about the material risks of and reasonably available alternatives to the proposed course of conduct." 227 The disclosures and explanation required to achieve informed consent necessarily depend on "the nature of the conflict and the nature of the risks involved" in the representation. ${ }^{228}$ And while a lawyer need not disclose to a client facts or implications about which the client already knows, ${ }^{229}$ a lawyer who withholds or glosses over material information pertinent to the client's decision whether to consent to the conflict assumes the risk that the client will in fact be uninformed and that any consent obtained will prove to be invalid. ${ }^{230}$

The amount of information necessary for the client to make an informed decision varies, but often pivots on the client's level of sophistication, education, and experience, and whether the client has independent counsel. ${ }^{231}$ The more experienced a client is in legal matters generally, and in making decisions of the type involved in the case in which consent is sought in particular, the less information and explanation needed for a client's consent to be informed. ${ }^{232}$

Depending on the complexity or nature of the matter, the lawyer may want to advise the client to seek independent counsel to help evaluate the conflict of interest. ${ }^{233}$ Generally, a client who is represented by

226. Model Rules of Prof'L Conduct r. 1.7(b)(4) (AM. BAR Ass'N 2019).

227. Id. r. $1.0(\mathrm{e})$.

228. Id. r. 1.7 cmt. 18; see also MJK Family LLC v. Corp. Eagle Mgmt. Servs., 676 F. Supp. $2 \mathrm{~d}$ 584, 597 (E.D. Mich. 2009) ("The amount of disclosure required . . depends on the circumstances.").

229. Galderma Labs., L.P. v. Actavis Mid Atl. LLC, 927 F. Supp. 2d 390, 401-02 (N.D. Tex. 2013).

230. Model Rules of Prof'L Conduct r. 1.0 cmt. 6 (AM. BAR Ass'N 2019).

231. Galderma Labs., 927 F. Supp. 2d at 401-03.

232. See N.Y.C. Bar Ass'n Comm. on Prof'l \& Judicial Ethics, Formal Op. 2001-2 (2001), https://www.nycbar.org/member-and-career-services/committees/reportslisting/reports/detail/formalopinion-2001-2-conflicts-in-corporate-and-transactional-matters [https://perma.cc/T4MK-H747] ("To be sure, sophisticated corporate and institutional clients can consent to conflicts which might be non-consentable in cases involving unsophisticated lay clients who are not represented by independent counsel in connection with the consent.").

233. Model Rules of Prof'L Conduct r. 1.0 cmt. 6 (AM. BAR Ass’n 2019). 
independent counsel is presumed to have given informed consent to the proposed course of conduct. ${ }^{234}$ This is true regardless of whether the other lawyer is the client's in-house counsel or an outside lawyer. ${ }^{235}$ To maximize the likely enforceability of the consent, lawyers should give clients adequate time to consider the information bearing on their decisions or to consult independent counsel. Absent exigent circumstances, insisting that the client wait a reasonable time before consenting to the conflict will undermine any later argument that the client was unable to reflect on the situation or solicit another lawyer's advice.

Regrettably, lawyers too often fail to achieve clients' informed consent to conflicts of interest. ${ }^{236}$ Roosevelt Irrigation District v. Salt River Project Agricultural Improvement and Power District ${ }^{237}$ is an environmental case in point.

Roosevelt Irrigation District was a CERCLA cost recovery action in which the Roosevelt Irrigation District (RID) sought to recover its costs incurred in addressing the contamination of its groundwater wells. ${ }^{238}$ In October 2008, RID hired the Phoenix law firm of Gallagher \& Kennedy to first investigate and then pursue its claims through negotiation or litigation. ${ }^{239}$ At the time, Gallagher \& Kennedy shareholder James Busby was representing Honeywell International (Honeywell) in a tax matter that had begun in May 2008 and ended in February 2009. ${ }^{240}$ RID ultimately sued various PRPs in February 2010, including Honeywell. ${ }^{241}$ Suing Honeywell proved to be consequential because two Gallagher \& Kennedy lawyers who were not involved in the CERCLA case, James Derouin and Glen Hallman, had previously represented Honeywell in substantially related matters-Derouin while at another law firm and Hallman as in-

234. Id.

235. See Galderma Labs., 927 F. Supp. 2d at 400 (finding that for the purposes of determining informed consent, it does not matter whether the independent lawyer is in-house or outside counsel).

236. See, e.g., Cedar Rapids Bank \& Tr. Co. v. Mako One Corp., 919 F.3d 529, 536 (8th Cir. 2019) (explaining the law firm's disclosure failures and concluding that the firm did not obtain the defendant's informed consent to the conflict of interest, such that the defendant's consent to the conflict was invalid); Johnson v. Clark Gin Serv., Inc., No. 15-3290 c/w 15-3314, 2016 WL 7017267, at *12 (E.D. La. Dec. 1, 2016) (finding no informed consent where the plaintiffs' lawyers had their clients agree that they would not assert certain causes of action so as to avoid conflicts of interest among them rather than the lawyers explaining to their clients the implications of joint representation).

237. 810 F. Supp. $2 d 929$ (D. Ariz. 2011).

238. Id. at 937.

239. Id.

240. Id. at 957.

241. See id. at 938 (identifying Honeywell as one of two PRPs that moved to disqualify Gallagher $\&$ Kennedy from representing RID). 
house counsel. ${ }^{242}$

In September 2010, Honeywell moved to disqualify Gallagher \& Kennedy based on Derouin's and Hallman's prior representation of it. ${ }^{243}$ RID countered that Honeywell had waived any conflict of interest in July 2009 while Busby represented it in the tax matter. ${ }^{244}$ Specifically, in July 2009, Gallagher \& Kennedy had written to Honeywell's in-house tax counsel to explain that the firm's environmental group was representing RID in connection with the contamination of its wells and that this representation could create a concurrent client conflict of interest with Honeywell. ${ }^{245}$ The letter asked Honeywell to waive the conflict and stated as follows:

[U]nder the ethical rules governing lawyers, $\mathrm{G} \& \mathrm{~K}$ and its attorneys may not oppose a current client (such as Honeywell), even on an unrelated matter, without full disclosure and consent. ... At this time, $\mathrm{G} \& \mathrm{~K}$ is seeking Honeywell's waiver and approval to allow G \& K to pursue settlement negotiations with Honeywell on behalf of RID in this matter. If litigation becomes necessary, RID would engage separate counsel to pursue the litigation, unless $\mathrm{G} \& \mathrm{~K}$ 's conflict is waived by Honeywell at that time. ${ }^{246}$

Honeywell "conditionally" consented to Gallagher \& Kennedy's representation of RID three days later. ${ }^{247}$

The Roosevelt Irrigation District court rejected RID's waiver argument for good reason. For one thing, Honeywell certainly had no reason based on Gallagher \& Kennedy's letter to anticipate the firm's representation of RID in litigation against it absent additional consultation. ${ }^{248}$ For another thing, but relatedly, Honeywell never gave informed consent to Gallagher \& Kennedy's conflict. ${ }^{249}$ Although not apparent from the portion of the firm's waiver letter quoted in the opinion, the letter did not adequately disclose Honeywell's former lawyers' relationship with Gallagher \& Kennedy. ${ }^{250}$ The letter referred only to

\footnotetext{
242. Id. at $938-39$.

243. Id. at 939 .

244. Id. at 957.

245. Id.

246. Id. (quoting the waiver letter).

247. Id.

248. Id. at 958 . The waiver letter suggested that Gallagher \& Kennedy was seeking a conflict waiver solely with respect to the tax matter and further stated that Gallagher \& Kennedy would not represent RID in litigation against Honeywell absent Honeywell's specific consent at the appropriate time. $I d$.

249. Id. at $958-59$.

250. Id. at 959 .
} 
Derouin's prior representation of Honeywell while at his former law firm; it did not mention Derouin's relocation to Gallagher \& Kennedy. ${ }^{251}$ Plus, the letter said nothing about Hallman's presence at the firm. ${ }^{252}$ Finally, there was no sign that Gallagher \& Kennedy ever attempted to ensure that Honeywell had any other information it might need to make an informed decision whether to waive the firm's conflict tied to the CERCLA litigation. ${ }^{253}$ The court therefore granted Honeywell's motion to disqualify Gallagher \& Kennedy. ${ }^{254}$

Roosevelt Irrigation District highlights for lawyers the importance of meaningful communication with clients when seeking consent to a conflict of interest and the peril of relying solely on correspondence for that purpose. In short, letters and e-mail messages:

[Do] not supplant the need in most cases for the lawyer to talk with the client, to explain the risks and advantages, if any, of representation burdened with a conflict of interest, as well as reasonably available alternatives, and to afford the client a reasonable opportunity to consider the risks and alternatives and to raise questions and concerns. ${ }^{255}$

As for the writing requirement, it is essential to remember that Model Rule 1.7 does not require a client's written consent to a conflict of interest; it requires that the client's consent be confirmed in writing. ${ }^{256}$ Thus, a lawyer may obtain the client's consent in a meeting or over the telephone, for example, and comply with the rule through a confirming letter, e-mail message, or text message. E-mail and text messages are "writings" in this context. $^{257}$ State rules of professional conduct, however, may vary. ${ }^{258}$

\section{The Enforceability of Advance Conflict Waivers}

While lawyers may seek consent from clients at the time a concurrent conflict of interest arises, it is also ethically permissible for lawyers to obtain advance consent to future conflicts of interest. ${ }^{259}$ In fact, this

\footnotetext{
251. Id.

252. Id

253. Id. (quoting ARIZ. RULE OF PROF'L CONDUCT $1.0 \mathrm{cmt} .6$ (2019)).

254. Id. at 986 .

255. Model Rules of Prof'L ConduCt r. 1.7 cmt. 20 (AM. BAR AsS'N 2019).

256. Id. r. $1.7(\mathrm{~b})(4)$.

257. Id. r. $1.0(\mathrm{n})$.

258. See, e.g., CAL. RULES OF PROF'L Conduct r. 1.7(a) \& (b) (2018) (requiring each client's "informed written consent" to concurrent conflicts of interest).

259. Model Rules of Prof'L CONDUCT r. 1.7 cmt. 22 (AM. BAR ASS'N 2019); ABA Comm. on Ethics \& Prof'1 Responsibility, Formal Op. 05-436, at 1, 4-5 (2005); D.C. Bar, Legal Ethics Comm.,
} 
practice is common where sophisticated clients are concerned. ${ }^{260}$ The overarching test for the enforceability of advance conflict waivers remains the client's informed consent. ${ }^{261}$ The lawyer bears the burden of proving the client's informed consent. ${ }^{262}$

Whether a court will consider consent to an advance waiver informed ordinarily depends on several factors, including the waiver's specificity and scope; the caliber of the discussion between the lawyer and the client concerning the conflict; the nature of the conflict at hand; the client's sophistication; whether independent counsel represented the client in giving consent; and "the interests of justice." 263 Like any other agreement between a lawyer and a client, a court will narrowly construe the scope of an advance waiver and resolve any ambiguities against the lawyer. ${ }^{264}$

Based on the fact-intensive nature of the informed consent inquiry, there are few bright line rules guiding lawyers as to the enforceability of advance waiver provisions. For that matter, because of the frequent difficulty of achieving informed consent, advance waiver provisions that might be characterized as open-ended are notoriously unreliable insurance against future disqualifying conflicts despite their ethical permissibility. ${ }^{265}$

Op. 309 (2001), https://www.dcbar.org/bar-resources/legal-ethics/opinions/opinion309.cfm [https:// perma.cc/R7YA-V2JK] [hereinafter D.C. Op. 309]; N.Y.C. Bar Ass'n Comm. on Prof'l \& Judicial Ethics, Formal Op. 2006-1 (2006), https://www.nycbar.org/member-and-career-services/committees /reports-listing/reports/detail/formal-opinion-2006-1-multiple-representations-informed-consentwaiver-of-conflicts [https://perma.cc/7P9G-PQPP] [hereinafter N.Y.C. Ethics Op. 2006-1].

260. Max-Planck-Gesellschaft zur Föerderung der Wissenschaften E.V. v. Whitehead Inst. for Biomedical Research, 850 F. Supp. 2d 317, 324 (D. Mass. 2011).

261. Galderma Labs., L.P. v. Actavis Mid Atl. LLC, 927 F. Supp. 2d 390, 396 (N.D. Tex. 2013); Visa U.S.A., Inc. v. First Data Corp., 241 F. Supp. 2d 1100, 1106 (N.D. Cal. 2003); see ModEL RULES OF PROF'L CONDUCT r. 1.7 cmt. 22 (AM. BAR ASS'N 2019) (“The effectiveness of [advance] waivers is generally determined by the extent to which the client reasonably understands the material risks that the waiver entails."); D.C. Op. 309, supra note 259 (explaining the importance of the client's informed consent when giving advance consent to a conflict); N.Y.C. Ethics Op. 2006-1, supra note 259 (explaining that an advance conflicts waiver requires the client's informed consent).

262. Galderma Labs., 927 F. Supp. 2d at 398.

263. W. Sugar Coop. v. Archer-Daniels-Midland Co., 98 F. Supp. 3d 1074, 1082-83 (C.D. Cal. 2015) (citing Visa U.S.A., 241 F. Supp. 2d at 1106); Lennar Mare Island, LLC v. Steadfast Ins. Co., 105 F. Supp. 3d 1100, 1115 (E.D. Cal. 2015) (citing Visa U.S.A., 241 F. Supp. 2d at 1106).

264. See, e.g., GSI Commerce Sols., Inc. v. BabyCenter, LLC, 618 F.3d 204, 212-13 (2d Cir. 2010) (concluding that the lawsuit in question did not fall into the category of cases covered by the parties' advance waiver provision); In re Rail Freight Fuel Surcharge Antitrust Litig., 965 F. Supp. 2d 104,118 n.12 (D.D.C. 2013) (rejecting the law firm's argument that the advance waiver covered the client's entire corporate family); Brigham Young Univ. v. Pfizer, Inc., No. 2:06-CV-890 TS BCW, 2010 WL 3855347, at *2-3 (D. Utah Sept. 29, 2010) (construing the advance waiver to apply to the law firm's clients with open intellectual property matters as of the day the consenting client signed the agreement, as opposed to covering all of the law firm's current and future clients with intellectual property matters).

265. See, e.g., S. Visions, LLP v. Red Diamond, Inc., 370 F. Supp. 3d 1314, 1327 (N.D. Ala. 2019) ("[G]iven the advance waivers' lack of specificity, the lack of evidence that Red Diamond was fully 
On the other hand, the closer the actual conflict of interest is to that which the parties contemplated at the time the client agreed to the advance waiver, the more likely it is that a court will enforce the waiver. ${ }^{266}$ Furthermore, while a clear link between the prospective and actual conflicts is certainly desirable, a lack of specificity regarding an identifiable future client or matter encompassed by the waiver does not necessarily render an advance conflict waiver unenforceable. ${ }^{267}$ An openended advance waiver may still be enforceable if the language outlines an approach to determining the firm's obligations should a conflict surface, "adequately explains the material risk to [the client] of waiving future conflicts of interest," and identifies for the client "reasonably available alternatives to the proposed course of conduct." 268 This is particularly true where the client is sophisticated. ${ }^{269}$ Of course, an advance waiver will not excuse a lawyer's failure to disclose a known current conflict of interest. ${ }^{270}$

\section{FORMER CLIENT CONFLICTS OF INTEREST}

As with current client relationships, lawyers' relationships with

counseled regarding their import, and especially the fact that directly adverse litigation between two direct competitors like Red Diamond and Southern Visions is an extremely serious conflict most clients would be unwilling to waive, the court is unable to conclude that the advance waivers, standing alone, provided Red Diamond's effective consent to this conflict."); Mylan, Inc. v. Kirkland \& Ellis LLP, No. 15-581, 2015 WL 12733414, at*18-19 (W.D. Pa. June 9, 2015) (rejecting an advance conflicts waiver for lack of informed consent).

266. David D. Dodge, Eye on Ethics: Advance Waivers to Potential Conflicts, ARIZ. ATT'Y, Jan. 2009, at 8, 8; see MODEL RULES OF PROF'L CONDUCT r. 1.7 cmt. 22 (AM. BAR Ass'N 2019) (“[I]f the client agrees to consent to a particular type of conflict with which the client is already familiar, then the consent ordinarily will be effective with regard to that type of conflict.").

267. See, e.g., Simpson Strong-Tie Co. v. Oz-Post Int'1, LLC, No. 3:18-cv-01188-WHO, 2018 WL 3956430, at*14-19 (N.D. Cal. Aug. 17, 2018) (commenting on the scope of the advance waiver and ultimately declining to disqualify the law firm).

268. See, e.g., In re Fisker Auto. Holdings, Inc. Shareholder Litig., No. 13-2100-DBS-SRF, 2018 WL 3991470, at *4 (D. Del. Aug. 20, 2018) (upholding an advance waiver); Macy's Inc. v. J.C. Penny Corp., 968 N.Y.S.2d 64, 65-66, (App. Div. 2013) (reasoning that the advance waiver was adequate, and that the plaintiffs' law firm should not be disqualified).

269. In re Fisker, 2018 WL 3991470 , at *4 (noting that the client was "experienced in hiring large national law firms" in a case in which the law firm whose advance waiver was challenged was a large national law firm); Galderma Labs., L.P. v. Actavis Mid Atl. LLC, 927 F. Supp. 2d 390, 402-03 (N.D. Tex. 2013) (discussing the client's sophistication in enforcing an advance waiver).

270. See, e.g., Galderma Labs., 927 F. Supp. 2d at 402-03 ("If a conflict of interest is known to an attorney at the time he seeks a waiver, the attorney is not allowed to hide that conflict, regardless of whether the client is sophisticated or not."); Sheppard, Mullin, Richter \& Hampton, LLP v. J-M Mfg. Co., 425 P.3d 1, 17 (Cal. 2018) ("Because this case concerns the failure to disclose a current conflict, we have no occasion here to decide whether, or under what circumstances, a blanket advance waiver ... would be permissible. We conclude, rather, that without full disclosure of existing conflicts known to the attorney, the client's consent is not informed for purposes of our ethics rules." (footnote omitted)). 
former clients may create conflicts of interest. ${ }^{271}$ This is true in environmental law as elsewhere. In fact, one of the seminal former client conflict cases frequently cited by courts, GTE North, Inc. v. Apache Products Co. ${ }^{272}$ arose out of a CERCLA cost recovery action. ${ }^{273}$

Former client conflicts are regulated under state ethics rules based on Rule 1.9 of the Model Rules of Professional Conduct. ${ }^{274}$ Model Rule 1.9 provides:

(a) A lawyer who has formerly represented a client in a matter shall not thereafter represent another person in the same or a substantially related matter in which that person's interests are materially adverse to the interests of the former client unless the former client gives informed consent, confirmed in writing.

(b) A lawyer shall not knowingly represent a person in the same or a substantially related matter in which a firm with which the lawyer formerly was associated had previously represented a client

(1) whose interests are materially adverse to that person; and

(2) about whom the lawyer had acquired information protected by Rules 1.6 and $1.9(\mathrm{c})$ that is material to the matter; unless the former client gives informed consent, confirmed in writing.

(c) A lawyer who has formerly represented a client in a matter or whose present or former firm has formerly represented a client in a matter shall not thereafter:

(1) use information relating to the representation to the disadvantage of the former client except as these Rules would permit or require with respect to a client, or when the information has become generally known; or

(2) reveal information relating to the representation except as these Rules would permit or require with respect to a client. ${ }^{275}$

Model Rule 1.9 and state analogs aim to protect a former client's reasonable expectation that confidential information a lawyer or law firm acquires during a representation will not later be used to the former client's

271. "If a lawyer represents a client in more than one matter, the client is a current client if any of those matters is active or open." ABA Comm. on Ethics \& Prof'l Responsibility, Formal Op. 481, at 6 (2018). "[T]he termination of representation in one or more matters does not transform a client into a former client if the lawyer still represents the client in other matters." Id.

272. 914 F. Supp. 1575 (N.D. Ill. 1996).

273. Id. at $1577-78$.

274. Model Rules of Prof'L CONDUCT r. 1.9 (AM. BAR Ass'N 2019).

275. Id. 
detriment when the lawyer or law firm is asked to undertake a new representation adverse to the former client. ${ }^{276}$ And even where confidentiality is not a concern, Rule 1.9 ensures lawyers' continuing duty of loyalty to former clients, ${ }^{277}$ although only to the extent that the matters implicating the lawyer's duty of loyalty are the same or substantially related. ${ }^{278}$ Most former client conflict controversies involve Rule 1.9(a).

\section{A. Model Rule 1.9(a) Conflicts}

For there to be a conflict of interest under Model Rule 1.9(a), the lawyer's current and prior representations must involve either the same matter or substantially related matters. ${ }^{279}$ A superficial resemblance or incidental similarity between the two matters is insufficient. ${ }^{280}$ Rather, two matters should be considered substantially related if (1) "they involve the same transaction or legal dispute"; or (2) "there otherwise is a substantial risk that confidential factual information as would normally have been obtained in the prior representation would materially advance the client's position in the subsequent matter."281 Accordingly, the "substantial relationship test" can be broken down into two separate inquiries: Does the current representation involve the same work the lawyer performed for the former client? Alternatively, is there a substantial risk that the lawyer acquired confidential information in the former client's representation that would materially advance the new client's representation? ${ }^{282}$ The first question asks about matter-specific conflicts, while the second inquires about information-specific conflicts.

\section{Analyzing Matter-Specific Conflicts of Interest}

For a matter-specific conflict of interest to materialize under Model

276. Pa. Bar Ass'n Comm. on Legal Ethics \& Prof'l Responsibility, Formal Op. 2012-100, at 1 (2012), http://www.pabar.org/members/catalogs/Ethics\%20Opinions/formal/f2012-100.pdf [https:// perma.cc/G57Q-MVU4] [hereinafter Pa. Ethics Op. 2012-100].

277. Utah State Bar Ethics Adv. Op. Comm., Op. 12-01, at 2 (2012), https://www.utahbar.org/wpcontent/uploads/2017/11/2012-01.pdf [https://perma.cc/AVM4-Z2H7] [hereinafter Utah Ethics Op. 12-01].

278. See GeOfFrey C. HaZARD, JR. ET Al., The Law OF LAwYering § 14.07, at 14-15 (4th ed. 2013 \& Supp. 2018) (describing lawyers' duty of continuing loyalty as "something of a misnomer, because lawyers may take adverse legal action against a former client, no matter how antagonistic or serious (and thus 'disloyal'), so long as the matters are not substantially related." (footnote omitted)).

279. MOdel RULES OF PROF'L CONDUCT r. 1.9(a) (AM. BAR Ass'N 2019).

280. Nev. Yellow Cab Corp. v. Eighth Judicial Dist. Ct. of Nev., 152 P.3d 737, 742 (Nev. 2007); Foley-Ciccantelli v. Bishop's Grove Condo. Ass'n, 797 N.W.2d 789, 815 (Wis. 2011).

281. Model Rules of PROF'L Conduct r. 1.9 cmt. 3 (AM. BAR Ass'N 2019).

282. RESTATEMENT (THIRD) OF THE LAW GOVERNing LAWYERS $§ 132$ (AM. LAW INST. 2000). 
Rule 1.9(a), "the matters must merely involve the same transaction or legal dispute." 283 Whether current and former matters involve the same transaction or legal dispute is determined by inquiring into whether the two matters are factually related. ${ }^{284}$ The matters must turn on the same facts of a particular situation or transaction, as opposed to simply involving the same type of legal issues. ${ }^{285}$ The comments to Model Rule 1.9 elaborate on this point:

When a lawyer has been directly involved in a specific transaction, subsequent representation of other clients with materially adverse interests in that transaction clearly is prohibited. On the other hand, a lawyer who recurrently handled a type of problem for a former client is not precluded from later representing another client in a factually distinct problem of that type even though the subsequent representation involves a position adverse to the prior client. ${ }^{286}$

A distinction therefore exists between pursuing a claim against a former client on a specific transaction or legal dispute versus adversity centered on a category or type of legal problem that a lawyer handled on a recurring basis. $^{287}$

Regarding the first scenario, the duty of loyalty prohibits a lawyer from depriving a former client of the benefit of the lawyer's work on the former client's behalf. ${ }^{288}$ It is thus generally accepted that a current matter is substantially related to a former client's representation if the current matter involves the same work the lawyer performed for the former client. ${ }^{289}$ This brand of former client conflict of interest is particularly severe when a lawyer attacks her earlier work or legal advice - a situation sometimes colloquially characterized as fouling one's own nest. ${ }^{290}$

283. In re Conduct of Hostetter, 238 P.3d 13, 23 (Or. 2010) (emphasis omitted).

284. Watkins v. Trans Union, LLC, 869 F.3d 514, 520 (7th Cir. 2017); Newton v. Stoneridge Apts., 424 P.3d 1086, 1091 (Utah Ct. App. 2018); see MOdEL RULES OF Prof'L CONDUCT r. 1.9 cmt. 2 (AM. BAR ASS'N 2019) (explaining that the scope of a matter depends on the facts of a specific situation or transaction).

285. Watkins, 869 F.3d at 521 (quoting IND. RULES OF PROF'L CONDUCT r. 1.9 cmt. 2).

286. Model RUles of PROF'L CONDUCT r. 1.9 cmt. 2 (AM. BAR Ass'N 2019).

287. See, e.g., Schaefer v. Gen. Elec. Co., No. 3:07-CV-0858 (PCD), 2008 WL 649189, at*11 (D. Conn. Jan. 22, 2008) ("To the extent Schaefer worked on individual discrimination claims as in-house counsel to GE, such work entailed a 'recurrently handled type of problem,' in which case Rule 1.9 is not implicated by her working on a new and wholly distinct gender class action discrimination claim." (citations omitted)).

288. Model RULES OF PROF'L CONDUCT r. 1.9 (AM. BAR ASS'N 2019).

289. In re Conduct of Hostetter, 238 P.3d 13, 21-23 (Or. 2010); RESTATEMENT (THIRD) OF THE LAW GOVERNING LAWYERS § 132(1) (AM. LAW INST. 2000).

290. See, e.g., Annie Sloan Interiors, Ltd. v. Kappel, No. 19-807, 2019 WL 2492303, at *1-3 (E.D. La. June 14, 2019) (alleging breach of fiduciary duty and violation of Rule 1.9(a) where the lawyer 
In contrast to scenarios where a lawyer attacks her prior work for the client, it is ordinarily permissible for a lawyer who has repeatedly handled a general type of legal problem for a client to later oppose that client in a factually distinct case. "Where a lawyer handles recurrent yet factually distinct problems," the factual information that a lawyer acquires in a representation is "not necessarily relevant to later matters"; hence, "there is no substantial risk that the [lawyer] could use the information to gain an unfair advantage." 291 The upshot is that while a lawyer clearly cannot switch sides in a specific transaction or matter, the lawyer's representation adverse to a former client in the same type of legal matter that she handled for the former client may be a different story. ${ }^{292}$ Model Rule 1.9(a) allows for representations opposite former clients to touch upon the particular problem area in which legal advice was previously rendered. When two matters "rely on the same legal theories but involve different facts, the two

helped a client register its trademarks and later represented another client in attacking the trademarks); Acad. of Allergy \& Asthma in Primary Care v. La. Health Serv. \& Indem. Co., 384 F.Supp.3d 644, 659-60 (E.D. La. 2018) (concluding that representations "are substantially related where counsel advises its current client on the subject matter it had previously advised its former client, in an effort to help the current client to prevail over the former on a critical issue shared between the two representations"; the law firm "placed itself in the position of attacking its own prior advocacy made on behalf of its former client"); Paul v. Judicial Watch, Inc., 571 F. Supp. 2d 17, 21-22 (D.D.C. 2008) (disqualifying a lawyer who supervised the negotiation and drafting an agreement as Judicial Watch's general counsel, then represented the plaintiff against Judicial Watch in a matter directly arising from that agreement; the "very type of 'changing of sides in the matter' forbidden by Rule 1.9"); Oasis W. Realty, LLC v. Goldman, 250 P.3d 1115, 1124-25 (Cal. 2011) (holding that a former client stated claims for breach of fiduciary duty, professional negligence, and breach of contract where the lawyer represented the client in obtaining a city council's approval for a redevelopment project, and two years later campaigned to thwart the project by soliciting signatures on a petition to overturn the project's approval); ASI Holding Co. v. Royal Beach \& Golf Resorts, LLC, 163 So. 3d 668, 670-71 (Fla. Dist. Ct. App. 2015) (disqualifying a law firm because its representation placed it in a position of "attacking the validity of the very document that it had previously represented to be valid and legally binding"); In re Basco, 221 S.W.3d 637, 639 (Tex. 2007) (disqualifying a hospital's defense lawyer and his law firm because the lawsuit required him to challenge the validity of his former law partner's legal advice to the plaintiff doctor).

291. Villas at Highland Park Homeowners Ass'n v. Villas at Highland Park, LLC, 394 P.3d 1144, 1153 (Colo. 2017); see ABA Comm. on Ethics \& Prof'l Responsibility, Formal Op. 99-415, at 5 n.10 (1999) [hereinafter ABA Formal Op. 99-415] (explaining that "it is not sufficient for the matters merely to be problems of a similar type" for purposes of the substantial relationship test); RESTATEMENT (THIRD) OF THE LAW GOVERNING LAWYERS § $132 \mathrm{cmt}$. d(iii) (AM. LAW INST. 2000) (observing that "a lawyer may master a particular substantive area of the law while representing a client, but that does not preclude a lawyer from representing another client adversely to the first in a matter involving the same legal issues, if the matters factually are not substantially related").

292. See Watkins v. Trans Union, LLC, 869 F.3d 514, 521-22 (7th Cir. 2017) (stating that where a lawyer defended Trans Union in hundreds of Fair Credit Reporting Act (FCRA) cases over a twoyear period, and almost ten years later represented a FCRA plaintiff against Trans Union, the representations did not turn on the same facts of one particular situation or transaction because the plaintiff's FCRA claim was unique to him and not interwoven with any case in which the lawyer had represented Trans Union). 
matters are not generally considered to be substantially related."293

\section{Analyzing Information-Specific Conflicts}

Even if the prior and current matters do not involve the same transaction or legal dispute, they are still substantially related if there is "a substantial risk that confidential factual information as would normally have been obtained [by the lawyer] in the prior representation would materially advance the [new] client's position in the subsequent matter." ${ }^{294}$ This aspect of the substantial relationship test is information specific and assumes the view of a hypothetical reasonable lawyer. ${ }^{295}$ The crux of the issue is "whether a reasonable lawyer would perceive a substantial risk that a competent attorney would normally have learned confidential factual information during the prior representation that could be used against the former client in the new matter." 296

To prove there is a substantial risk that the lawyer has confidential information that could harm the former client's interests in the subsequent matter, the former client is not required to divulge the confidential information allegedly disclosed to the lawyer. ${ }^{297}$ A contrary rule would ironically force former clients to reveal the very confidences and secrets Rule 1.9 is intended to protect. ${ }^{298}$ As a result, courts focus on the nature of the legal services that the lawyer provided the former client and the kind

293. United States ex rel. Bumbury v. Med-Care Diabetic \& Med. Supplies, Inc., 101 F. Supp. 3d 1268, 1275 (S.D. Fla. 2015). See, e.g., Nicholas v. Grapetree Shores, Inc., No. 05-119, 2013 WL 1196960, at *6 (D.V.I. Mar. 21, 2013) (observing that a lawyer is not precluded from representing a client adverse to a former client simply because the cases involve "the same legal issues if the matters factually are not substantially related"); Health Care \& Ret. Corp. of Am., v. Bradley, 961 So.2d 1071, 1072-74 (Fla. Dist. Ct. App. 2007) (finding no substantial relationship where the lawyer defended a nursing home in over sixty cases alleging negligence tied to residents' pressure ulcers and falls and later left his law firm and sued the nursing home alleging neglect and failure to monitor the development of residents' pressure ulcers; the subsequent representation was a "wholly distinct problem" that turned on its own facts).

294. Model Rules of PROF’L CONDUCT r. 1.9 cmt. 3 (AM. BAR AsS’N 2019).

295. N.Y. State Bar Ass'n Comm. on Prof'l Ethics, Op. 871 (2011), https://www.nysba.org/ CustomTemplates/Content.aspx?id=5204 [https://perma.cc/2QDC-92LV].

296. Id.

297. Bowers v. Ophthalmology Grp., 733 F.3d 647, 651 (6th Cir. 2013); Velazquez-Velez v. Molina-Rodriguez, 235 F. Supp. 3d 358, 362 (D.P.R. 2017) (quoting Starlight Sugar Inc. v. Soto, 903 F. Supp. 261, 266 (D.P.R. 1995)); Headfirst Baseball LLC v. Elwood, 999 F. Supp. 2d 199, 2111 (D.D.C. 2013) (quoting Derrickson v. Derrickson, 541 A.2d 149, 151 (D.C. 1988)); Koch v. Koch Indus., 798 F. Supp. 1525, 1536 (D. Kan. 1992); N.Y. State Bar Ass'n, Comm. on Prof'l Ethics, Op. 1008 (2014), https://www.nysba.org/CustomTemplates/Content.aspx?id=49178 [https://perma.cc/S KJ6-A4NT] [hereinafter N.Y. Ethics Op. 1008]; Pa. Ethics Op. 2012-100, supra note 276, at 3.

298. W. Sugar Coop. v. Archer-Daniels-Midland Co., 98 F. Supp. 3d 1074, 1088 (C.D. Cal. 2015) (citing Trone v. Smith, 621 F.2d 994, 999 (9th Cir. 1980)); N.Y. Ethics Op. 1008, supra note 297; Pa. Ethics Op. 2012-100, supra note 276, at 3-4. 
of confidential factual information that the lawyer would have typically received during the representation. ${ }^{299}$ This may include examining whether "(a) the lawyer and the client ought to have talked about particular facts during the course of the representation, or (b) the information is of such a character that it would not have been unusual for it to have been discussed between lawyer and client during their relationships." $" 300$

Evidence that a lawyer actually received confidential information relating to the prior representation is unnecessary for Rule 1.9(a) purposes. $^{301}$ If it is reasonable to infer that the lawyer received information during the first representation that might be useful in the second representation, thereby creating a substantial risk of exploitation of that information, then the two matters are substantially related. ${ }^{302}$ All the same, proof of the lawyer's "actual receipt of confidential information in the prior matter [is] even more compelling than a mere likelihood of its receipt." 303 A former client's conclusory or unsupported allegations that she shared confidential information during the prior representation, however, ought not be considered. ${ }^{304}$

The existence of a substantial relationship triggers the presumption that the lawyer possesses confidential information that can be used for the current client's benefit and the former client's detriment. ${ }^{305}$ In most jurisdictions, the presumption is irrebuttable. ${ }^{306}$ In others, it is "rebuttable

299. Bowers, 733 F.3d at 652-53; Headfirst Baseball LLC, 999 F. Supp. 2d at 210-11; Villas at Highland Park Homeowners Ass'n v. Villas at Highland Park, LLC, 394 P.3d 1144, 1153 (Colo. 2017).

300. Pa. Ethics Op. 2012-100, supra note 276, at 4; see also Atmosphere Hosp. Mgmt. Servs., LLC v. Royal Realties, LLC, 28 F. Supp. 3d 692, 697 (E.D. Mich. 2014) (expressing the same test (quoting Alpha Capital Mgmt., Inc. v. Rentenbach, 792 N.W.2d 344, 356-57 (Mich. Ct. App. 2010)).

301. Analytica, Inc. v. NPD Research, Inc., 708 F.2d 1263, 1266 (7th Cir. 1983); Annie Sloan Interiors, Ltd. v. Kappel, No. 19-807, 2019 WL 2492303, at*7 (E.D. La. June 14, 2019); In re Conduct of Hostetter, 238 P.3d 13, 23 (Or. 2010).

302. Fernandez v. St. Francis Hosp., No. 09C-03-008-JRS, 2009 WL 2393713, at *3 (Del. Super. Ct. Aug. 3, 2009).

303. N.Y. Ethics Op. 1008, supra note 297; see N.Y. State Bar Ass'n, Comm. on Prof'l Ethics, Op. 922 (2012), https://www.nysba.org/CustomTemplates/Content.aspx?id=3723 [https://perma.cc/Y TM5-2PFE] (recognizing that matters are "substantially related if the lawyer in question actually and knowingly obtained (and now possesses) confidential factual information that would materially advance the prospective client's position in the subsequent matter").

304. Aubrey v. D Mag. Partners, L.P., No. 3:19-CV-0056-B, 2019 WL 2103699, at *2 (N.D. Tex. May 14, 2019); Worley v. Moore, 807 S.E.2d 133, 140 (N.C. 2017).

305. N. Am. Deed Co. v. Joseph, 334 B.R. 443, 455 (Bankr. D. Nev. 2005); Koch v. Koch Indus., 798 F. Supp. 1525,1536 (D. Kan. 1992).

306. United States v. Prevezon Holdings Ltd., 839 F.3d 227, 240 (2d Cir. 2016) (quoting DeFazio v. Wallis, 459 F. Supp. 2d 159, 164-65 (E.D.N.Y. 2006) (collecting cases)); United States v. Stiger, 413 F.3d 1185, 1196 (10th Cir. 2005) (quoting Smith v. Whatcott, 757 F.2d 1098, 1100 (10th Cir. 1985)), overruled on other grounds by United States v. Ellis, 868 F.3d 1155, 1175 (10th Cir. 2017); Perillo v. Johnson, 205 F.3d 775, 800 (5th Cir. 2000); Mt. Hebron Dist. Missionary Baptist Ass'n of 
but difficult to overcome." 307

Applying this framework has proven to be laborious because of the varying ways in which courts articulate the substantial relationship analysis. One line of authority concentrates on a fact-based comparison of the two matters. ${ }^{308}$ Another line of authority holds that the present and prior representations must involve common subject matters, issues, or legal problems. ${ }^{309} \mathrm{~A}$ third line of authority requires the relationship between the matters to be "patently clear" or for the matters to sport "identical issues." 310 Finally, a fourth approach focuses on the similarities between the factual circumstances and legal theories of the current and former representations, as well as the degree of the lawyer's

Ala., Inc. v. Sentinel Ins. Co., No. 3:16-cv-658-CDL-GMB, 2017 WL 3928269, at *6 (M.D. Ala. Sept. 7, 2017); Janczewski v. Janczewski, 94 N.Y.S.3d 142, 145 (App. Div. 2019); In re Thetford, 574 S.W.3d 362, 373 (Tex. 2019).

307. In re MCK Millennium Ctr. Retail, LLC, 571 B.R. 783, 786 (Bankr. N.D. Ill. 2017) (citing LaSalle Nat'l Bank v. Lake Cty., 703 F.2d 252, 257 (7th Cir. 1983)).

308. See, e.g., Whatcott, 757 F.2d at 1100 (requiring "the factual contexts of the two representations [to be] similar or related" (quoting Tr. Corp. of Mont. v. Piper Aircraft Corp., 701 F.2d 85, 87 (9th Cir. 1983)); FMC Techs., Inc. v. Edwards, 420 F. Supp. 2d 1153, 1159 (W.D. Wash. 2006) (applying a "'factual context' test"); Koch, 798 F. Supp. at 1536 (focusing on "the similarities between the factual bases of the two representations" and noting that "[a] commonality of legal claims or issues is not required"); In re Thetford, 574 S.W.3d at 374 ("[P]roducing specific overlapping facts is necessary to show substantial relation, [but] it is not sufficient. ... [T] hose facts [must further] create a genuine threat of disclosure" (internal quotation marks omitted)); ABA Formal Op. 99-415, supra note 291, at 23 (stating that the standard "inevitably requires a factual inquiry comparing the two matters").

309. See, e.g., In re Am. Airlines, Inc., 972 F.2d 605, 625 (5th Cir. 1992) (explaining that the "two representations need only involve the same 'subject matter' in order to be substantially related"); Acad. of Allergy \& Asthma in Primary Care v. La. Health Serv. \& Indem. Co., 384 F. Supp. 3d 644, 657-58 (E.D. La. 2018) (concluding that representations are substantially related where a lawyer advises a current client on the subject matter she had previously advised a former client about to help the current client prevail over the former client on a critical issue common to both representations); FDIC ex rel. AmTrust Bank v. Commonwealth Land Title Ins. Co., No. 1:08CV2390, 2012 WL 3912764, at*7 (N.D. Ohio Sept. 7, 2012) (requiring a "commonality of issues between the prior and present representation" (quoting Campbell v. Indep. Outlook, Inc., No. 04AP-310, 2004 WL 2892884, at *3 (Ohio Ct. App. Dec. 14, 2004)); Estate of Pew, 655 A.2d 521, 545 (Pa. Super. Ct. 1994) (stating that the fact that representations involve similar or related facts is not alone sufficient, but "rather the test is whether information acquired by an attorney in his former representation is substantially related to the subject matter of subsequent representation").

310. See, e.g., Gov’t of India v. Cook Indus., Inc., 569 F.2d 737, 739-40 (2d Cir. 1978) (“Such considerations have ... [honed] the 'substantial relationship' test ... to granting disqualification only upon a showing that the relationship between issues in the prior and present cases is 'patently clear'.... [D]isqualification has been granted or approved recently only when the issues involved have been 'identical' or 'essentially the same'." (citations omitted)); Calamar Enters., Inc. v. Blue Forest Land Grp., LLC, 222 F. Supp. 3d 257, 265-66 (W.D.N.Y. 2016) (requiring a patently clear relationship between the matters); Giambrone v. Meritplan Ins. Co., 117 F. Supp. 3d 259, 272 (E.D.N.Y. 2015) (requiring the relationship between the issues in the two cases to be "patently clear"); Revise Clothing, Inc. v. Joe's Jeans Subsidiary, Inc., 687 F. Supp. 2d 381, 392 (S.D.N.Y. 2010) (quoting Gov't of India, 569 F.2d at 739-40); Becker v. Perla, 5 N.Y.S.3d 34, 35 (App. Div. 2015) (requiring the issues in the competing matters to be "identical or essentially the same"). 
involvement. $^{311}$

As one might expect, whether prior and current representations are substantially related is a fact-intensive inquiry. ${ }^{312}$ Considerations that may guide the analysis include (1) the scope of the representations set forth in the engagement letters; (2) whether the matters share a common subject matter, legal issues, causes of action, or key witnesses or evidence; (3) whether the matters involve the same events, or a series of matters or transactions that reveal the former client's pattern of conduct; (4) whether time has rendered all or part of the former client's information obsolete; (5) whether the former client's information has since been disclosed to the public; (6) whether the lawyer's knowledge of the former client's "playbook," that is, its operations, litigation strategies, business practices, negotiating philosophy, ability to satisfy debts, or decision-making is relevant to the current matter; (7) the duration of the lawyer's relationship with the clients; and (8) the nature of the lawyer's services. ${ }^{313}$

\section{Representative Cases}

State ex rel. Swanson v. $3 M \mathrm{Co}^{314}$ is an interesting former client conflict case with environmental law roots. In Swanson, the global law

311. See, e.g., Zerger \& Mauer LLP v. City of Greenwood, 751 F.3d 928, 933 (8th Cir. 2014) ("To determine if matters are substantially related, we must examine the factual and issue relationship between the two representations."); Leapfrog Enters., Inc. v. Epik Learning, LLC, No.16-cv-04269EDL, 2017 WL 2986604, at *8 (N.D. Cal. Feb. 23, 2017) ("The existence of a substantial relationship depends on the similarities between the two factual situations, the legal questions posed, and the nature and extent of the attorney's involvement."); Jessen v. Hartford Cas. Ins. Co., 3 Cal. Rptr. 3d 877, 88788 (Ct. App. 2003) (deeming two matters substantially related when "[confidential] information material to the evaluation, prosecution, settlement or accomplishment of the former representation given its factual and legal issues is also material to the evaluation, prosecution, settlement or accomplishment of the current representation given its factual and legal issues"); Villas at Highland Park Homeowners Ass'n v. Villas at Highland Park, LLC, 394 P.3d 1144, 1153 (Colo. 2017) (describing the substantial relationship test as "a process of factual reconstruction' that 'cannot be limited to the consideration of ultimate legal issues, but must account for facts and circumstances, [the underlying] legal theories and strategies [and facts that would be necessary to prove or disprove those theories], and even the nature and scope of the attorney's involvement in the former representation" (quoting People v. Frisco, 119 P.3d 1093, 1096 (Colo. 2005)); State ex rel. Swanson v. 3M Co., 845 N.W.2d 808, 816 (Minn. 2014) (analyzing "the extent to which the factual and legal issues in the two representations overlap"); State ex rel. Wal-Mart Stores, Inc. v. Kortum, 559 N.W.2d 496, 501 (Neb. 1997) (focusing on the similarity of the factual and legal issues in both cases).

312. Highland Park Homeowners Ass' $n, 394$ P.3d at 1153; Foley-Ciccantelli v. Bishop's Grove Condo. Ass'n, 797 N.W.2d 789, 815 (Wis. 2011); Pa. Ethics Op. 2012-100, supra note 276, at 4; Utah Ethics Op. 12-01, supra note 277, at 2.

313. United States ex rel. Bumbury v. Med-Care Diabetic \& Med. Supplies, Inc., 101 F. Supp. 3d 1268, 1275-76 (S.D. Fla. 2015); Chrispens v. Coastal Ref. \& Mktg., Inc., 897 P.2d 104, 112 (Kan. 1995); In re Carey, 89 S.W.3d 477, 494 (Mo. 2002) (quoting Chrispens, 897 P.2d at 112); Kortum, 559 N.W.2d at 501; Worley v. Moore, 807 S.E.2d 133, 140 (N.C. 2017).

314. 845 N.W.2d 808 (Minn. 2014). 
firm Covington \& Burling, LLP (Covington) found trouble when it represented the State of Minnesota (the State) in litigation against the 3M Co. ${ }^{315}$ The litigation involved 3M's manufacture and disposal of perfluorochemicals (PFCs). ${ }^{316}$ Covington had previously represented $3 \mathrm{M}$ in connection with 3M's development of fluorochemical (FC) products. ${ }^{317}$

In 1992, 3M retained Covington lawyer Peter Hutt to represent it in securing FDA approval for FC food packaging products. ${ }^{318}$ Hutt's representation of $3 \mathrm{M}$ later expanded to include a range of advice on legal and regulatory issues affecting 3M's FC products. ${ }^{319}$ Although $3 \mathrm{M}$ stopped manufacturing FCs domestically in 2000, Covington continued to represent $3 \mathrm{M}$ on FC-related matters until $2006{ }^{320}$ In the process, the firm's lawyers obtained information from $3 \mathrm{M}$ about the health effects of FC exposure. ${ }^{321}$

In 2007, 3M entered into an agreement with the Minnesota Pollution Control Agency (MPCA) that required 3M to help abate PFC pollution. ${ }^{322}$ Conjunctively, $3 \mathrm{M}$ had to disclose numerous documents regarding the environmental and health effects of PFCs, including documents regarding the treatment and disposal of PFC waste and its characterization as hazardous. $^{323} 3 \mathrm{M}$ also had to work with the MPCA and another state agency to formulate health and toxicology studies related to PFCs. ${ }^{324}$

In May 2010, 3M hired Covington in regard to a retiree benefits issue. ${ }^{325}$ Covington finished that matter in September 2010. ${ }^{326}$ In November 2010, the State approached Covington about representing it in natural resource damages (NRD) litigation against $3 \mathrm{M}$ for discharging PFCs into surface and ground waters. ${ }^{327}$ Covington was a logical choice for the State because the firm had previously represented it in environmental matters. ${ }^{328}$ On December 22, 2010, Covington asked 3M

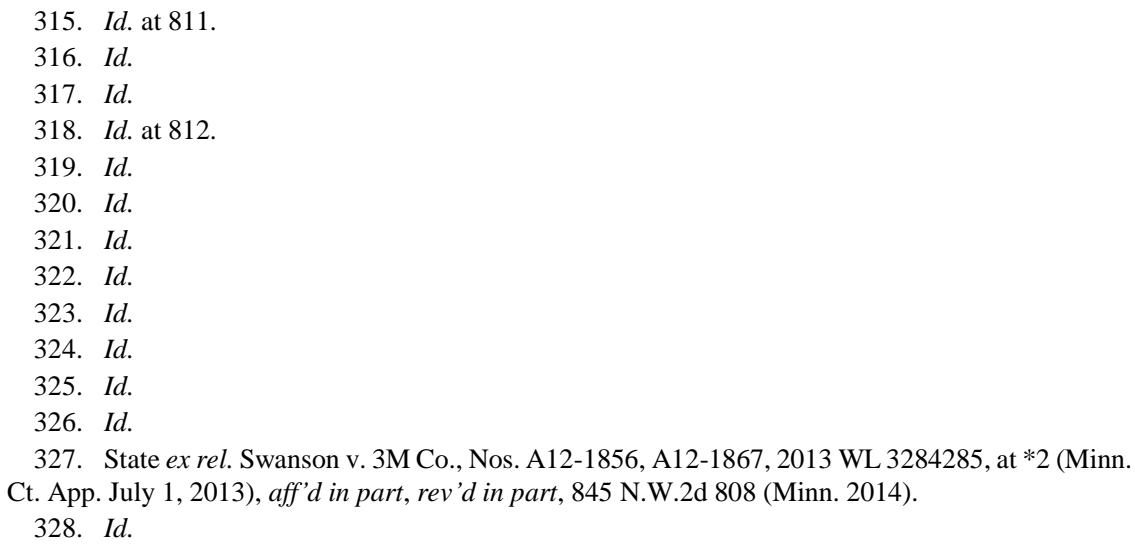


to send an e-mail formally terminating the firm's representation on the retiree benefits matter; $3 \mathrm{M}$ promptly complied. ${ }^{329}$ A week later, Covington began representing the State in the NRD litigation on a contingent fee basis. ${ }^{330}$ The firm entered its appearance in the NRD case in January 2011 . $^{331}$

The parties engaged in voluminous and expensive discovery. ${ }^{332}$ Discovery was scheduled to close on June 1, 2012. ${ }^{333}$ In late March 2012, $3 \mathrm{M}$ 's lead outside lawyer in the NRD case, William Brewer, sent a letter to Covington in which he stated: "It has just come to our attention that Covington previously represented $3 \mathrm{M}$ for the purpose of providing $3 \mathrm{M}$ with legal advice concerning legal and regulatory issues associated with its fluorochemical business." 334 3M demanded that Covington withdraw from the State's representation in the NRD litigation but Covington refused. ${ }^{335}$

In fact, between Covington's first appearance in the NRD case and 3M's demand that Covington withdraw, 3M's then-general counsel Marschall Smith twice signaled to Covington lawyers that he knew that the firm may have a conflict of interest. ${ }^{336}$ More particularly:

Smith exchanged e-mails with Covington attorney Daniel Spiegel on April 8, 2011... A Although Spiegel initially replied that he was unaware of the [NRD] case, Spiegel sent a second e-mail confirming Covington's representation of the State .... Spiegel explained that Covington had performed work for 3M before Smith's tenure but "the work stream from 3M basically ended." Smith responded, "Sure, makes perfect sense . . . you do have to represent your clients. Nothing personal. Hope we can get back to you after this is over." ... [I]n a November 16, 2011 letter to Covington attorneys Mitchell Dolin and Benedict Lenhart, Smith wrote, "We did not raise the conflict issue when you filed the lawsuit on behalf of the State, but perhaps we should have."337

In April 2012, 3M moved to disqualify Covington as counsel for the

329. Id. at *1.

330. $I d$. at $* 2$.

331. State ex rel. Swanson, 845 N.W.2d at 812 .

332. See id. at 813 ("“A]s of November 8,2012 , the parties had produced more than six million pages of documents and deposed more than 70 witnesses. Between December 30, 2010, and October 11,2012 , Covington devoted more than 20,000 hours of attorney time to the NRD case and incurred between $\$ 2$ million and \$3 million in litigation expenses.").

333. Id.

334. Id. (quoting the letter) (internal quotation marks omitted).

335. Id.

336. Id.

337. Id. 
State, arguing that Minnesota's version of Rule 1.9(a) barred Covington from representing the State in the NRD case because the NRD case was substantially related to the firm's earlier work for 3M in FC matters. ${ }^{338}$ Soon thereafter, $3 \mathrm{M}$ separately sued Covington in a Minnesota state court for breach of fiduciary duty and breach of contract tied to the firm's representation of the State in the NRD case. ${ }^{339}$

In October 2012, the trial court in the NRD case held that Covington had violated Rule 1.9(a) and disqualified the firm as counsel for the State. ${ }^{340}$ The court reasoned that the NRD case and Covington's representation of $3 \mathrm{M}$ in its FC business were substantially related matters because both involved the potential health and environmental effects of FC exposure. ${ }^{341}$ The court also concluded that a client cannot impliedly waive the right to disqualify its former lawyer. ${ }^{342}$

The State and Covington each appealed to the Minnesota Court of Appeals, which affirmed the trial court's disqualification order. ${ }^{343}$ Both the State and Covington then successfully petitioned the Minnesota Supreme Court for review. ${ }^{344}$

After deciding that Covington had standing to appeal the disqualification order, the Swanson court focused on whether the NRD litigation was substantially related to Covington's representation of $3 \mathrm{M}$ in FC matters. ${ }^{345}$ The court thus had to "analyze the extent to which the factual and legal issues in the two representations overlap and examine any other relevant circumstances." ${ }^{346}$ The court also needed to consider whether confidential information that $3 \mathrm{M}$ shared with Covington in its prior representation had since been publicly disclosed and whether the information had become obsolete due to the passage of time. ${ }^{347}$

The trial court had determined that Covington learned confidential information in its prior representation of $3 \mathrm{M}$ in FC matters. ${ }^{348}$ The trial

338. Id.

339. See id. ("3M allege[d] that Covington failed to protect client confidences, breached its duties of candor and full disclosure, and breached its duty of loyalty by taking a position materially adverse to $3 \mathrm{M}$ in the NRD case.").

340. Id.

341. Id. at $813-14$.

342. See id. at 814 ("The district court also concluded that a client cannot impliedly waive the right to disqualify the opposing party's counsel based on a violation of Rule 1.9(a).”).

343. Id.

344. Id.

345. Id. at 816 .

346. Id. (footnote omitted) (citing State ex rel. McClanahan v. Hamilton, 430 S.E.2d 569, 572-73 (W. Va. 1993)).

347. Id. at 817 (citing MinN. Rules OF PROF'L CONDUCT r. 1.9 cmt. 3 (2019)).

348. Id. 
court further presumed that the information was shared with all Covington lawyers. ${ }^{349}$ Unfortunately, the trial court did not (1) meaningfully evaluate Covington's claims that the pertinent information was no longer confidential because 3M had disclosed it to the MPCA and the public; or (2) analyze whether $3 \mathrm{M}$ waived its attorney-client privilege by suing Covington. ${ }^{350}$ Nor did the trial court consider whether there was a significant risk that the State could exploit any of 3M's remaining confidential information in the NRD case. ${ }^{351}$ As a result, the trial "court abused its discretion by failing to [analyze] all legally relevant factors" before determining that the NRD case and the FC matters were substantially related. ${ }^{352}$

The Swanson court next recognized that a party may waive the right to disqualify opposing counsel based on a Rule 1.9(a) conflict. ${ }^{353}$ In doing so, ${ }^{354}$ the Swanson court aligned itself with most courts to have considered the issue. ${ }^{355}$

Having found that a party may waive a conflict of interest, the court examined whether $3 \mathrm{M}$ had waived Covington's conflict. 356 "Waiver" requires a party's "knowledge of the right" in question and the "intent to waive it." 357 Factors that circumstantially evidence a party's intent to waive opposing counsel's disqualification include "(1) the length of the delay in bringing the motion to disqualify, (2) whether the movant was represented by counsel during the delay, and (3) the reason for the delay." 358 A court evaluating waiver allegations should also "consider any relevant actions and statements" by the allegedly waiving party. ${ }^{359}$ In this

\footnotetext{
349. Id.

350. Id.

351. Id.

352. Id. (citing State v. Freeman, 531 N.W.2d 190, 198 (Minn. 1995)).

353. Id. at $817-18$.

354. In recognizing waiver in this context, the Swanson court was careful to note that it was not diminishing lawyers' ethical obligations under Rule 1.9(a). Id. at 818. As the court explained, a lawyer's ethical obligations under Rule 1.9(a) exist regardless of whether a client waives the right to seek the lawyer's disqualification for a Rule 1.9(a) conflict. Id. A court's "finding of waiver in the context of ongoing litigation will not preclude other remedies for violating Rule 1.9(a), including attorney disciplinary action or a separate lawsuit against the attorney for breach of fiduciary duty." Id. at $818-19$.

355. Id. at 818 \& n.5 (collecting cases).

356. Id. at 819 .

357. Id.

358. Id. (citing Alexander v. Primerica Holdings, Inc., 822 F. Supp. 1099, 1115 (D.N.J. 1993); Commonwealth Ins. Co. v. Graphix Hot Line, Inc., 808 F. Supp. 1200, 1208 (E.D. Pa. 1992); Emp'rs. Ins. of Wausau v. Albert D. Seeno Constr. Co., 692 F. Supp. 1150, 1165 (N.D. Cal. 1988)).

359. Id. (citing Local 1142 v. United Elec., Radio \& Mach. Workers of Am., 76 N.W.2d 481, 484 (Minn. 1956)).
} 
case:

The district court did not conduct an implied-waiver analysis, but in rejecting the State's waiver argument, the district court discussed the dispute regarding when $3 \mathrm{M}$ became aware of the extent of Covington's prior representation of $3 \mathrm{M}$. The district court's findings regarding the timing focus on the personal knowledge of then-3M General Counsel Smith. The district court found that Smith lacked actual knowledge of the potential conflict when the NRD case was filed. The district court also found that 3M's outside counsel ... did not learn of the potential conflict until March 2012 and promptly sought Covington's disqualification thereafter. ${ }^{360}$

But the trial court's concentration on Smith's and Brewer's knowledge was analytically flawed because:

To be legally relevant, the analysis must focus on the party to whom the right belongs. Because $3 \mathrm{M}$ [was] the party with the right to object to any conflict, the legally relevant point in time for determining the length of the delay in asserting the right to seek disqualification [was] when $3 \mathrm{M}$ [was] deemed to have learned of the conflict. ... Here, in addition to whether and when Smith and Brewer acquired actual knowledge of the potential conflict, the inquiry must consider whether other $3 \mathrm{M}$ employees or agents, such as other $3 \mathrm{M}$ in-house counsel, already held knowledge that is relevant to determining when $3 \mathrm{M}$ learned of the potential conflict. ${ }^{361}$

Considering its decision that implied waiver is not a defense to a disqualification motion, the trial court never performed the intensely factual waiver analysis that was required. ${ }^{362}$ The resulting lack of factual findings prevented the Swanson court from effectively reviewing the State's and Covington's contentions that $3 \mathrm{M}$ waived its right to disqualify Covington. ${ }^{363}$

Finally, the State argued that even if $3 \mathrm{M}$ did not waive its right to seek Covington's disqualification and Covington violated Rule 1.9(a), the trial court "was not required to disqualify Covington because the equities weigh[ed] against disqualification." 364 The court made short work of this meritless argument, pointing out that Rule 1.9(a) controlled the case and mandated application of the substantial relationship test. ${ }^{365}$

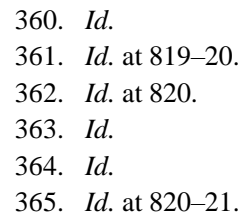


The Minnesota Supreme Court concluded that because the trial court did not consider all legally relevant factors in analyzing Covington's disqualification under Rule 1.9(a) and because it mistakenly reasoned that a party cannot impliedly waive the right to disqualify opposing counsel, the case should be remanded to the trial court for further proceedings. ${ }^{366}$ In February 2016, the trial court, on remand, held that Covington had violated Rule 1.9 but that $3 \mathrm{M}$ had waived the right to seek the firm's disqualification. ${ }^{367}$ In February 2017, Covington confidentially settled 3M's lawsuit against it. ${ }^{368}$ In February 2018, the State settled the NRD litigation for $\$ 850$ million, with Covington receiving a $\$ 150$ million contingent fee. ${ }^{369}$

Another recent Rule 1.9(a) case, Lane v. BP p.l.c., ${ }^{370}$ arose out of contamination emanating from an Oklahoma Superfund site known as the Wilcox Site. Years earlier, the land comprising the Wilcox Site had been home to an oil refinery. ${ }^{371}$

Bristow First Assembly of God (the Church) was located on the Wilcox Site. ${ }^{372}$ The Church's pastor, Mark Evans, and his family lived in the Church until the Oklahoma Department of Environmental Quality (ODEQ) warned them that remaining there would be unhealthy. ${ }^{373}$ In June 2015, the Evans family sued several defendants in an Oklahoma state court for negligence, nuisance, trespass, fraud and strict liability, including energy conglomerate Kinder Morgan, Inc. ${ }^{374}$ The Evanses were represented by three law firms: Durbin Larimore \& Bialick, Devore \& Jorgenson, PLC, and Michael J. Blaschke, P.C. ${ }^{375}$ Kinder Morgan removed the suit to federal court. ${ }^{376}$

A Kinder Morgan subsidiary, the El Paso Corporation (El Paso), had known about the contamination at the Wilcox Site since late 2011, when

366. Id. at 821 .

367. State v. 3M Co., No. 27-CV-10-28862, 2016 Minn. Dist. LEXIS 1, at*55 (Minn. Dist. Ct. Feb. 5, 2016).

368. Andrew Strickler, Covington Pays Out to End 3M 'Side-Switching' Ethics Suit, Law360 (Mar. 1, 2017), https://www.law360.com/articles/897028/covington-pays-out-to-end-3m-side-switchi ng-ethics-suit.

369. Katherine L. Nelson, State House Analyzes 3M Settlement in Committee, WoOdBURY BULL. (Mar. 8, 2018, 1:00 PM), https://www.woodburybulletin.com/news/government-and-politics/4414173 -state-house-analyzes-3m-settlement-committee [https://perma.cc/ALE3-75CP].

370. 2018 WL 4932002 (N.D. Okla. Oct. 11, 2018).

371. Id. at $* 1$.

372. Id.

373. Id.

374. Id.

375. Id. at $* 2$.

376. Id. at *1. 
ODEQ approached it about entering into a voluntary cleanup or Brownfields program to address contamination at the site. ${ }^{377}$ ODEQ was on El Paso's trail because the Wilcox Oil Co., which had operated the polluting refinery, had merged with the Tenneco Oil Co. in 1965, and El Paso had acquired Tenneco in 1996. ${ }^{378}$ Kinder Morgan acquired El Paso in 2012. ${ }^{379}$

After ODEQ's overture, El Paso retained David Kearney, then a partner at the GableGotwals law firm, to investigate the company's involvement with the Wilcox Site. ${ }^{380}$ Kearney subsequently represented El Paso at a December 2011 meeting with ODEQ officials, collaborated with other GableGotwals lawyers in addressing ODEQ's claims, and helped ghostwrite a letter for El Paso's general counsel in which El Paso disclaimed responsibility for cleaning up the Wilcox Site. ${ }^{381}$ El Paso's denial of liability apparently rested on ODEQ's alleged failure to assert related claims against an entity known as the EPEC Oil Company Liquidating Trust (the Trust) within a prescribed ten-year period. ${ }^{382}$

In 2018, Kinder Morgan learned that Kearney, who was by then a partner at Durbin Larimore, had led GableGotwals's prior representation of El Paso. ${ }^{383}$ Kinder Morgan demanded that all three of the plaintiffs' law firms withdraw from the case based on Kearney's alleged conflict of interest. $^{384}$ When they refused, Kinder Morgan moved to disqualify Durbin Larimore. ${ }^{385}$

In the Tenth Circuit, which includes Oklahoma, "a party seeking to disqualify opposing counsel pursuant to [Rule] 1.9(a) must establish that (1) an actual attorney-client relationship existed between the moving party and the opposing counsel; (2) the present litigation involves a matter that is 'substantially related' to the subject of the movant's prior representation; and (3) the interests of the opposing counsel's present client are materially adverse to the movant." 386 "If the movant satisfies the first two prongs," there is an "irrebuttable presumption" that the client revealed information to the lawyer that requires the lawyer's

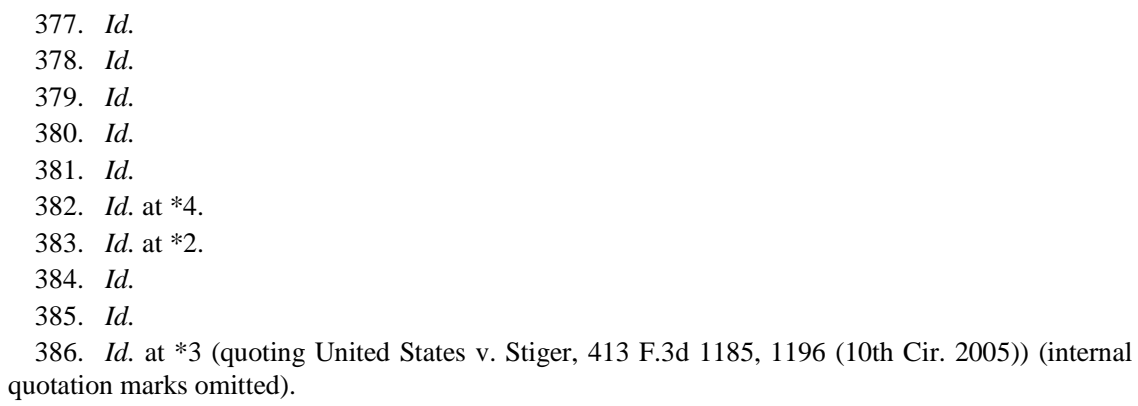


disqualification. ${ }^{387}$ Sequential matters are "substantially related" for purposes of Oklahoma's version of Rule 1.9(a) "if they involve the same transaction or legal dispute or if there otherwise is a substantial risk that confidential factual information as would normally have been obtained in the prior representation would materially advance the client's position in the subsequent matter." 388

It was clear that Kearney once shared an attorney-client relationship with El Paso and that Kinder Morgan later acquired El Paso. ${ }^{389}$ It was also clear that Kinder Morgan's interests and the plaintiffs' interests were materially adverse. ${ }^{390}$ The plaintiffs argued, however, that the two matters were not substantially related because only ODEQ and El Paso were parties to the prior matter and El Paso's only basis for then declining to participate in cleaning up the Wilcox Site was ODEQ's alleged failure to timely assert claims against the Trust. ${ }^{391}$ The plaintiffs reasoned that because Kinder Morgan had not raised ODEQ's failure to pursue the Trust as a defense in this case, there was no conflict of interest. ${ }^{392}$ The Lane court, however, rejected the plaintiffs' restrictive view of the relationship between the two matters:

Both matters involve[d] the alleged contamination of the Wilcox site by the former Wilcox Company, which merged with Tenneco Oil Company in 1965. El Paso is the successor to Tenneco and Kinder-Morgan acquired El Paso in May 2012. The Complaint in this case specifically reference[d] [ODEQ's] earlier attempt to persuade El Paso to participate in remediation of the Wilcox site and El Paso's rejection of that request based on the existence of the Trust - the very matters Mr. Kearney handled on behalf of El Paso. Plaintiffs are now pursuing ... damages and injunctive relief, based on the same alleged contamination. Accordingly, it is beyond question that the interests of Mr. Kearney's current clients - the plaintiffs in this case - are materially adverse to Kinder Morgan. ${ }^{393}$

The next question was whether Kearney's conflict of interest could be imputed to Durbin Larimore since Kearney was not counsel of record in the current case. ${ }^{394}$ The short answer under Oklahoma Rule of

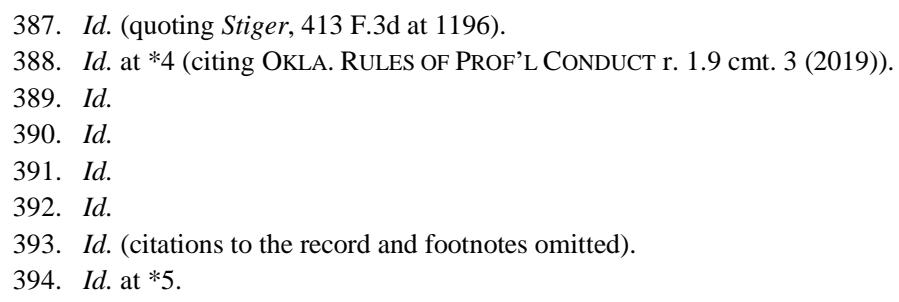


Professional Conduct 1.10(a) was yes. ${ }^{395}$

Retreating, the plaintiffs contended that because Kinder Morgan did not move to disqualify Durbin Larimore until the litigation was well underway, it had waived its right to seek the firm's disqualification. ${ }^{396}$ This argument received a chilly reception from the Lane court. As the court explained, the plaintiffs' argument was "not consistent with law or the professional rules and would place an undue burden on former clients to know every member of a law firm upon that firm's entry of appearance." ${ }^{397}$ Furthermore, Kearney never alerted Kinder Morgan to the issue, and Kinder Morgan was oblivious to the conflict until it reviewed thousands of documents in response to a discovery motion by the plaintiffs. ${ }^{398}$ Kinder Morgan learned of the dispute between El Paso and ODEQ when reviewing documents for production to the plaintiffs, matched Kearney to that matter, identified the conflict of interest, and moved to disqualify Durbin Larimore three days later. ${ }^{399}$ On those facts, the Lane court concluded that Kinder Morgan had acted reasonably promptly and that it had not waived its right to seek Durbin Larimore's disqualification. ${ }^{400}$

The Lane court granted Kinder Morgan's motion to disqualify Durbin Larimore. ${ }^{401}$ The DeVore Law Firm and Blaschke remained in the case for the plaintiffs. ${ }^{402}$

\section{Summary}

Absent client consent, Model Rule 1.9(a) prohibits a lawyer from representing a client if the proposed matter is the same or substantially related to a former client's matter, and the current and former clients' interests are materially adverse. ${ }^{403}$ The centerpiece of this standard, the substantial relationship test, normally requires an analysis of the factual and legal similarities of the two representations, as well as the nature and extent of the lawyer's involvement. The greater the similarities between

\footnotetext{
395. Id. Although Oklahoma's version of Rule 1.10(a) and Model Rule 1.10(a) differ, Kearney's conflict of interest would likewise have been imputed to Durbin Larimore under Model Rule 1.10(a). Id. 
the facts and the legal issues involved, the greater the chance that the two representations will be deemed to be substantially related.

From a risk management perspective, limiting the scope of the new client's representation may help a lawyer avoid disqualification in a matter that is substantially related to a former client's representation. As the District of Columbia Bar Legal Ethics Committee explained:

[A] lawyer may limit the scope of the new representation such that factual information normally obtained in the prior matter would be legally irrelevant to the advancement of the current client's position in the new matter. Specifically, by agreeing only to represent a client as to a discrete legal issue or with respect to a discrete stage in the litigation, a lawyer may be able to limit the scope of the representation such that the new matter is not substantially related to the prior matter. Restrictions on the scope of the representation that effectively ensure that there is no substantial risk that confidential factual information as would normally have been obtained in the prior representation would be useful or relevant to advance the client's position in the new matter may, under certain circumstances, be sufficient to avoid a conflict of interest. ${ }^{404}$

As to be expected, any limitation on the current client's representation must be reasonable under the circumstances and requires the client's informed consent. ${ }^{405}$

\section{B. Former Clients and Lawyers' Lateral Movement}

Lateral movement by lawyers between law firms is now common. ${ }^{406}$ Lawyers may change firms several times during their careers. These moves may create former client conflicts of interest for a lawyer and her new firm. Phrased as a question, when a lawyer changes law firms and seeks to represent a client in the same or substantially related matter in which the client's interests are materially adverse to the interests of a client from the lawyer's prior firm, does a former client conflict of interest disqualify the lawyer (and her new law firm) from that representation?

1. The Model Rule 1.9(b) Framework

In this era of lawyer mobility, Model Rule 1.9(b) offers specific

\footnotetext{
404. D.C. Bar Legal Ethics Comm., Op. 343 (2008), https://www.dcbar.org/bar-resources/legalethics/opinions/opinion343.cfm [https://perma.cc/2MDE-P2Q5].

405. Model RULES OF PROF'L CONDUCT r. 1.2(c) (AM. BAR ASS'N 2019).

406. See Graubard Mollen Dannett \& Horowtiz v. Moskovitz, 653 N.E.2d 1179, 1180 (N.Y. 1995) (calling "the revolving door" a "modern-day law firm fixture"); ABA Comm. on Ethics \& Prof"1 Responsibility, Formal Op. 09-455, at 1 (2009) ("Many lawyers change law firm associations during their careers.").
} 
guidance where a lawyer's previous law firm has represented the former client at issue. Model Rule 1.9(b) states:

A lawyer shall not knowingly represent a person in the same or substantially related matter in which a firm with which the lawyer formerly was associated had previously represented a client ... whose interests are materially adverse to that person; and ... about whom the lawyer had acquired information protected by Rules 1.6 and 1.9(c) that is material to the matter; unless the former client gives informed consent, confirmed in writing. . $^{4}$

By its terms, Model Rule 1.9(b) establishes three requirements for disqualifying a lawyer (and her current law firm by imputation) based on work performed for a client at the lawyer's prior law firm: (1) the current client's matter must be the same as, or substantially related to, the former client's matter; (2) the current and former clients' interests must be materially adverse; and (3) the lawyer must have acquired confidential information about the former client's matter that is material to the current client's matter. ${ }^{408}$

The third element is pivotal. A violation of Rule 1.9(b) only occurs if a lawyer at her prior law firm acquired confidential information about the former client that is material to the current client's matter. ${ }^{409}$ If while working at the prior law firm the lawyer acquired no knowledge or information relating to the particular client, and the lawyer subsequently joins a new law firm, then "neither the moving lawyer, nor the [lawyer's] new firm, are disqualified from representing" another client in the same or substantially related matter even though the two clients' interests conflict. ${ }^{410}$

Recall that under Model Rule 1.9(a), there generally is an irrebuttable presumption that a lawyer received the former client's confidential information in a substantially related matter. ${ }^{411}$ Under Rule $1.9(\mathrm{~b})$, it is presumed that a lawyer possesses material, confidential information through her association with her prior firm but this presumption is

407. Model Rules of Prof'L Conduct r. 1.9(b) (AM. BAR Ass'N 2019).

408. Id.

409. Nev. State Bar Comm. on Ethics \& Prof'1 Responsibility, Ethics Op. 39, at 2-3 (2008), https:/ /www.nvbar.org/wp-content/uploads/opinion_39.pdf [https://perma.cc/CZY2-GFNE] [hereinafter Nev. Ethics Op. 39]; Or. State Bar Ass'n, Ethics Op. 2005-120, at 4 (2016), https://www.osbar.org/_docs/ethics/2005-120.pdf [https://perma.cc/HFN9-6LQT]; MODEL RULES OF PROF'L CONDUCT r. 1.9 cmt. 5 (AM. BAR ASS'N 2019).

410. Nev. Ethics Op. 39, supra note 409, at 2-3.

411. See supra note 306 and accompanying text. 
rebuttable. ${ }^{412}$ The lawyer or her law firm bears the burden of proving the lawyer's lack of actual knowledge of the former client's material, confidential information. ${ }^{413}$ A lawyer's general access to a former client's protected information will not trigger Rule 1.9(b). ${ }^{414}$ If the lawyer does not have actual knowledge of the former client's protected information, disqualification is inappropriate..$^{415}$

\section{Screening to Avoid a Rule 1.9(b) Conflict of Interest}

If a lateral lawyer has actual knowledge of a former client's protected information, she may be able to avoid disqualification by obtaining the former client's consent to her representation of her current client. ${ }^{416}$ If the former client will not consent, under Model Rule 1.10(a)(2), the lawyer's new firm may nonetheless avoid imputation of the lawyer's conflict if the firm (1) timely screens the lawyer from participation in the matter; (2) apportions the lawyer no part of the related fee; and (3) promptly notifies the former client in writing, including, "a description of the [firm's] screening procedures employed [and] a statement of the firm's and of the screened lawyer's compliance with the[] Rules." 417 In short, Model Rule 1.10 (a)(2) allows the new law firm to unilaterally erect an ethical screen to avoid imputed disqualification. Approximately thirty states have adopted the Model Rule 1.10(a)(2) approach with some variation. ${ }^{418}$

Timely screening of the lateral lawyer is essential to avoid disqualification of the lawyer's firm, as Stimson Lumber Co. $v$. International Paper Co. ${ }^{419}$ demonstrates. There, Stimson Lumber Co.

412. Exterior Sys., Inc. v. Noble Composites, Inc., 210 F. Supp. 2d 1062, 1068 (N.D. Ind. 2002); Park Apts. at Fayetteville, LP v. Plants, 545 S.W.3d 755, 759 (Ark. 2018). But see New Horizon Kids Quest III, Inc. v. Eighth Jud. Dist. Ct., 392 P.3d 166, 169 (Nev. 2017) ("The requirement that the attorney actually acquire confidential information about his former firm's client is not a presumption; rather, it is a factual matter for the district court to resolve.").

413. Park Apts., 545 S.W.3d at 759; Model Rules of Prof'L CONDUCT r. 1.9 cmt. 6 (AM. BAR Ass'N 2019).

414. Park Apts., 545 S.W.3d at 757-59.

415. Baham v. Ass'n of Apt. Owners of Opua Hale Patio Homes, No. 13-00669HG-BMK, 2014 WL 413495, at *2 (D. Haw. Feb. 4, 2014) (quoting Dieter v. Regents of Univ. of Cal., 963 F. Supp. 908, 911 (E.D. Cal. 1997)). See, e.g., Commonwealth v. Cousin, 88 N.E.3d 822, $839-40$ (Mass. 2018) (declining to disqualify the lawyer under Rule 1.9(b)).

416. See Model Rules of Prof'L Conduct r. 1.9(a) (AM. BAR Ass'N 2019).

417. Id. r. $1.10(\mathrm{a})(2)$.

418. AM. BAR ASS'N, CPR POLICY IMPLEMENTATION COMM., VARIATIONS OF THE ABA MOdEL RULES OF PROF'L CONDUCT, RULE 1.10: IMPUTATION OF CONFLICTS OF INTEREST: GENERAL RULE (Dec. 11, 2018), https://www.americanbar.org/content/dam/aba/administrative/professional_responsi bility/lateralscreening.pdf [https://perma.cc/59J6-4AZV].

419. No. CV-10-79-M-DWM-JC, 2011 WL 124303 (D. Mont. Jan. 14, 2011). 
(Stimson) owned the Bonner Mill in Montana, home to a sawmill and a plywood manufacturing plant. ${ }^{420}$ Stimson had purchased the Bonner Mill from International Paper Co.'s (International) predecessor in interest, Champion International Corp. (Champion), in 1993. ${ }^{421}$ When Stimson faced the expensive cleanup of pollution at Bonner Mill, it sued International under CERCLA and the equivalent Montana statute. ${ }^{422}$ Stimson alleged that Champion was responsible for some portion of the property's contamination and that Champion's liability for remediation costs passed to International as its successor in interest. ${ }^{423}$

Stephen Brown and Elena Zlatnik of Garlington, Lohn \& Robinson (Garlington) were Stimson's local counsel. ${ }^{424}$ Brown previously represented Champion with respect to matters in dispute in the CERCLA case. ${ }^{425}$ In 1993, while an associate at another law firm, Brown worked on Champion's sale of the Bonner Mill to Stimson. ${ }^{426}$ The sale terms were squarely at issue in Stimson's suit against International. ${ }^{427}$ Brown also knew of certain environmental issues that Champion disclosed to Stimson when negotiating the sale. ${ }^{428}$

Prior to July 26, 2010, when Stimson filed suit, its lead counsel, Steve Olson, asked Brown to serve as Stimson's local counsel. ${ }^{429}$ Brown then ran a conflicts check which flagged his work for Champion on the sale of the Bonner Mill. ${ }^{430}$ Brown nevertheless agreed to represent Stimson in its suit against International and participated in the lawsuit as counsel of record for Stimson. ${ }^{431}$

On September 21, 2010, International's counsel, Thomas Grever, wrote to Brown to protest his conflict of interest based on his prior representation of Champion. ${ }^{432}$ Grever advised Brown that International did not consent to his representation of Stimson in the CERCLA case. ${ }^{433}$

On October 20, 2010, Brown wrote Grever back, asserting that his

\footnotetext{
420. Id. at $* 1$.

421. Id.

422. Id.

423. Id.

424. Id.

425. Id.

426. Id.

427. Id.

428. Id.

429. Id. at *4.

430. Id.

431. Id.

432. Id. at *5.

433. Id.
} 
prior legal work for Champion was unrelated to this case. ${ }^{434}$ Even so, Brown asked International Paper to waive the alleged conflict of interest. ${ }^{435}$ International declined his request. ${ }^{436}$

Given International's refusal to waive the conflict, Brown and Olson agreed that Brown should withdraw from Stimson's representation. ${ }^{437}$ Brown moved to withdraw on November 29, 2010. ${ }^{438}$ Around the same time, Garlington erected an ethical wall that insulated Brown from the firm's other lawyers who continued to represent Stimson in the case. ${ }^{439}$ Brown informed Grever of this precaution. ${ }^{40}$ Brown's and Garlington's efforts gave no comfort to International, however, which promptly moved to disqualify Brown, Zlatnik, and the entire Garlington firm from Stimson's representation. ${ }^{441}$

Garlington argued that disqualification was inappropriate because it had screened Brown from continued participation in the CERCLA case. ${ }^{442}$ The Stimson Lumber court rejected the firm's argument because its effort to screen Brown came too late. ${ }^{443}$ Brown began representing Stimson and actively participated in this case since late July 2010, yet the firm did not implement the ethical screen until the tail end of November 2010. ${ }^{444}$ As the court explained, "[w] here screening mechanisms are not immediately implemented, and are instead instituted only after the conflicted attorney's former client asserts the existence of a conflict, the ethical screen is not timely implemented." ${ }^{445}$ Furthermore, despite the screen, Brown continued to work in close proximity to Zlatnik and any other Garlington lawyers who might represent Stimson in the CERCLA litigation. ${ }^{446}$ This fact supported a conclusion that Garlington's ethical screen was ineffective. ${ }^{447}$




The Stimson Lumber court determined that Garlington had not timely screened Brown from participation in Stimson's lawsuit against International and that the firm's screening procedures were ineffective to boot. ${ }^{448}$ It accordingly granted International's motion to disqualify Zlatnik and Garlington. ${ }^{449}$

\section{The Material Adversity Requirement}

Both Model Rules 1.9(a) and (b) include a "material adversity" requirement. ${ }^{450}$ In other words, for there to be a conflict of interest under either rule, the current and former client's interests must be materially adverse in addition to the two representations being the same or substantially related. Although Rule 1.9 does not attempt to define material adversity, ${ }^{451}$ the issue is seldom contested. This is because most alleged conflicts relating to former clients arise when a lawyer is representing a new client suing a former client (or vice versa), and the alignment of the new and former clients as foes in litigation clearly satisfies the material adversity requirement. ${ }^{452}$ A more complicated question arises when a former client is not directly involved in the current matter at issue, but may be affected by it in some manner. Zerger \& Mauer LLP v. City of Greenwood ${ }^{453}$ is such a case.

Zerger \& Mauer LLP represented the city of Greenwood, Missouri (Greenwood) in a dispute with Martin Marietta Materials (Martin) arising out of a rock quarry located south of the city. ${ }^{454}$ The controversy centered on Martin truck traffic traveling through Greenwood and creating a public

conclusion is suspect. So long as Zlatnik and the other lawyers who might represent Stimson did not share information regarding the matter with Brown or somehow expose him to such information, and Brown otherwise respected the screen, their individual offices' proximity to one another should have been inconsequential.

448. Id.

449. Id.

450. Model Rules of Prof’L Conduct r. 1.9(a),(b)(1) (AM. BAR Ass’N 2019).

451. Some courts have attempted to characterize or describe "material adversity," if not define it. See, e.g., Foley-Ciccantelli v. Bishop's Grove Condo. Ass'n, 797 N.W.2d 789, 816 (Wis. 2011) ("The analysis should focus on whether the current representation may cause the former client financial, legal, or some other identifiable harm." (footnote omitted)); Simpson Performance Prods., Inc. v. Horn, 92 P.3d 283, 288 (Wyo. 2004) ("This fact-intensive analysis focuses on whether the current representation may cause legal, financial, or other identifiable detriment to the former client.").

452. See N.Y. State Bar Ass'n, Comm. on Prof'1 Ethics, Op. 1103 (2016), https://www.nysba.org/ CustomTemplates/Content.aspx?id=66270 [https://perma.cc/539E-WQP8] [hereinafter N.Y. Ethics Op. 1103] (stating that " $[\mathrm{t}]$ he 'materially adverse' prong of Rule 1.9(a) is always met when a former client is on the opposite side of a lawsuit involving the same or a substantially related matter, whether as plaintiff or defendant").

453. 751 F.3d 928 (8th Cir. 2014).

454. Id. at 929 . 
nuisance, with Martin finally settling for $\$ 7$ million. ${ }^{455}$ As part of the settlement, Greenwood designated Second Avenue for the truck traffic"the route it deemed most beneficial to the [c]ity" - and "declared that the truck traffic along that route was reasonable and was not a [public] nuisance. $" 456$

About one year later, Zerger \& Mauer filed a private nuisance action on behalf of multiple plaintiffs with property interests along Second Avenue against Martin and other entities involved in hauling rock from the quarry. ${ }^{457}$ Not long afterwards, Greenwood - now a non-party"moved to disqualify Zerger [\&] Mauer from representing the individual plaintiffs." "458 According to Greenwood, the firm was "advancing arguments in the [private nuisance] litigation that directly conflicted with Greenwood's interests." 459 The district court agreed and disqualified Zerger \& Mauer. ${ }^{460}$

The Eight Circuit affirmed the district court, first finding that the matters were substantially related. ${ }^{461}$ The Eighth Circuit also analyzed whether the plaintiffs' interests were materially adverse to Greenwood's interests. ${ }^{462}$ In the court's view, Greenwood's interests in its settlement agreement with Martin would be harmed if the plaintiffs' private nuisance claim disrupted Martin's use of Second Avenue, which would require Greenwood to open other trucking routes to Martin. ${ }^{463}$ Indeed, Zerger \& Mauer's current arguments targeting Martin's allegedly tortious use of Second Avenue contradicted a material term in the settlement agreement between Greenwood and Martin because Greenwood wanted to reserve Second Avenue as the exclusive route for truck traffic. ${ }^{464}$ As the Eighth Circuit succinctly stated, "Greenwood may demand that its former counsel not advocate positions that pose the serious threat of once again embroiling Greenwood in protracted litigation." ${ }^{465}$

In summary, whether a representation is materially adverse to a former client depends on a case-specific inquiry which evaluates the degree to

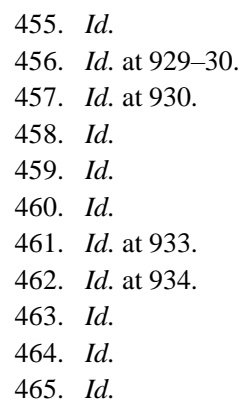


which the lawyer's current representation may harm the former client. ${ }^{466}$ The rub is whether the lawyer's current representation will cause legal, financial, or other identifiable detriment to the former client. ${ }^{467}$ The mere fact that the current client and the former client have competing economic interests, however, will not suffice. ${ }^{468}$

\section{ISSUE OR POSITIONAL CONFLICTS OF INTEREST}

Finally, environmental lawyers must be prepared to navigate issue or positional conflicts of interest. For example:

[O]ne client might wish to retain a lawyer to seek a ruling that a substance should not be listed as a hazardous substance in a particular category under the Resources Conservation and Recovery Act (RCRA). The lawyer he wishes to hire once worked for EPA and was involved in drafting an agency guidance document that classified waste as within the category of RCRA hazardous waste. Or, similarly, another client may instruct the lawyer to argue that the substance is a hazardous waste and should be listed under RCRA. ${ }^{469}$

It is true, of course, that lawyers may advocate any viable interpretation of the law to benefit a client on day one, and on day two represent another client and promote whatever non-frivolous position exists to benefit that client. ${ }^{470}$ The ability to advocate different and even competing positions in different matters is lawyers' stock-in-trade. Advocating opposite sides of the same issue on behalf of two current clients in unrelated matters, however, is the archetypal example of an issue or positional conflict of interest.

It is not "inherently improper" for a lawyer to simultaneously take inconsistent positions on behalf of different clients in different matters. ${ }^{471}$

466. Foley-Ciccantelli v. Bishop's Grove Condo. Ass'n, 797 N.W.2d 789, 816 (Wis. 2011); Simpson Performance Prods., Inc. v. Horn, 92 P.3d 283, 288 (Wyo. 2004).

467. Foley-Ciccantelli, 797 N.W.2d at 816; Simpson Performance Prods., Inc., 92 P.3d at 288.

468. See N.Y. Ethics Op. 1103, supra note 452 (permitting a representation where the current and former clients were industry competitors).

469. RUSSELL, supra note 3, at 309.

470. See Model Rules of Prof’L Conduct r. 1.7 cmt. 24 (AM. BAR Ass'N 2019) (“Ordinarily a lawyer may take inconsistent legal positions in different tribunals at different times on behalf of different clients. The mere fact that advocating a legal position on behalf of one client might create precedent adverse to the interests of a client represented by the lawyer in an unrelated matter does not create a conflict of interest.").

471. Alaska Bar Ass'n Ethics Comm., Op. 96-6, at 3 (1996),

https://alaskabar.org/wp-content/uploads/96-6.pdf [https://perma.cc/ENV9-N637]; D.C. Bar Legal Ethics Comm., Op. 265 (1996), https://www.dcbar.org/bar-resources/legalethics/opinions/opini on265.cfm [https://perma.cc/ZV22-UQBN] [hereinafter D.C. Op. 265]; MODEL RULES OF PROF'L 
Otherwise, lawyers would be forced to specialize on one side of legal issues. ${ }^{472}$ The facts and circumstances of a representation, however, may present a conflict severe enough to undermine a lawyer's credibility, and therefore impair the lawyer's ability to represent both clients. ${ }^{473}$ Plus, a successful outcome for one client may prejudice the other client, which, in turn, will likely jeopardize the attorney-client relationship, the quality of the representation, or both. ${ }^{474}$

Issue or positional conflicts of interest arise in litigation when a lawyer argues for an interpretation of the law on behalf of one client that is contrary to another client's interests. ABA Formal Opinion $93-377^{475}$ is a good starting point for understanding issue and positional conflicts in this context. In Formal Opinion 93-377, the ABA's Standing Committee on Ethics and Professional Responsibility reasoned that if a law firm litigates two cases on behalf of different clients in the same jurisdiction, and there is a substantial risk that the firm's representation of one client will create a legal precedent, even if not binding, which is likely to materially undercut the firm's legal position on behalf of the other client, a material limitation conflict exists under Model Rule 1.7(a)(2). ${ }^{476}$ Williams $v$. State $^{477}$ illustrates the quintessential positional conflict of interest where divergent legal positions are presented to the same court, albeit in a criminal matter rather than in an environmental law context.

Bernard O'Donnell defended Joseph Williams on first-degree murder charges. ${ }^{478}$ Following Williams' conviction and death sentence, O'Donnell moved to withdraw and requested the appointment of substitute counsel for Williams' appeal to the Delaware Supreme Court. ${ }^{479}$ In so moving, O'Donnell reasoned that Williams could argue on appeal that the trial court erred in affording "'great weight' to the jury's 10-2

\footnotetext{
CONDUCT r. 1.7 cmt. 24 (AM. BAR Ass'N 2019); see J.M.J. v. L.A.M., 791 N.W.2d 573, 581 (Minn. Ct. App. 2010) (holding that, where the trial court labeled the lawyer's advocacy against the legality of unmarried second parent, same-sex adoptions as "disingenuous" because he simultaneously advertised on his law firm's website that adoption services "may now be an option" for "unmarried couples and ... same-sex couples," the trial court's sanction of the lawyer was clearly erroneous under comment 24 to Model Rule 1.7, but affirming the sanction on other grounds).

472. ReSTATEMENT (ThiRD) OF THE LAW GOVERNING LAWYERS § $128 \mathrm{cmt}$. f (AM. LAW. INST. 2000).

473. D.C. Op. 265, supra note 471.

474. Id.

475. ABA Comm. on Ethics \& Prof'1 Responsibility, Formal Op. 93-377 (1993) [hereinafter ABA Formal Op. 93-377].

476. Id. at 3 .

477. 805 A.2d 880 (Del. 2002).

478. Id. at 880 .

479. Id. at $880-81$
} 
recommendation in favor of the death penalty," and "that he may have a conflict in presenting this argument." 480 Specifically, O'Donnell explained that he had urged a contrary position on behalf of another capital murder defendant in a pending Delaware Supreme Court appeal: in the second case he asserted that the trial court erred "when it failed to give great weight to the jury's 2-10 vote rejecting the imposition of the death penalty." 481 Based on these clearly divergent positions, O'Donnell worried "that his representation of both clients" would risk creating "unfavorable precedent... for one client or the other," and invite questions as to his overall credibility and perceived loyalty to each client. $^{482}$

In determining whether a positional conflict required O'Donnell's disqualification, the Delaware Supreme Court articulated the governing standard as follows:

[T] he question is whether the lawyer can effectively argue both sides of the same legal question without compromising the interests of one client or the other. The lawyer must attempt to strike a balance between the duty to advocate any viable interpretation of the law for one client's benefit versus the other client's right to insist on counsel's fidelity to their legal position. ${ }^{483}$

Applying this benchmark, the Williams court agreed that O'Donnell had identified a disqualifying positional conflict of interest. ${ }^{484}$ Indeed, the court held that O'Donnell would violate Delaware's version of Rule 1.7 if he advocated conflicting legal positions in two capital murder appeals pending simultaneously before the court. ${ }^{485}$

Williams displays positional conflicts in litigation at their most extreme: (1) setting legal precedent in favor of one client, but adverse to another client; and (2) eroding a lawyer's credibility with the court by advocating opposing sides of the same legal issue. Even when the cases are in different jurisdictions, however, a lawyer urging opposite sides of a legal issue must still evaluate whether the representation of either client will materially limit the lawyer's effectiveness in the other matter. ${ }^{486}$ In that situation, the risk of an issue or positional conflict is particularly acute

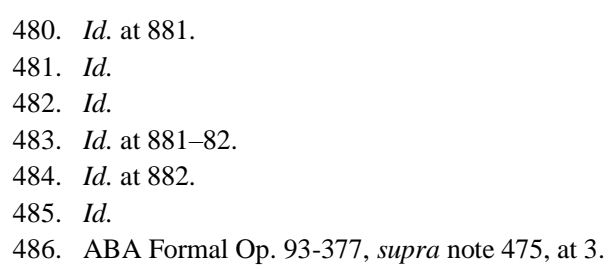


where the arguments involve a new or emerging area of the law and the first-decided case will likely be regarded as persuasive authority by a court in another jurisdiction. ${ }^{487}$

In the lobbying context, issue or positional conflicts may surface where a law firm argues for a change in the law on behalf of one client that will detrimentally affect another current client who is lobbying, litigating, or promoting a position that is adverse to the first client's position. ${ }^{488}$ Positional conflicts in lobbying, like their litigation counterparts, require a lawyer to navigate potential credibility issues before legislative bodies, breaches of confidentiality through the use or disclosure of client confidences to advance another client's interests, and clients' expected loyalty to their cause. ${ }^{489}$ The District of Columbia, as a focal point for lobbying activities in the United States, has implemented its own set of conflicts rules for legislative lobbying engagements. ${ }^{490}$

Three questions serve as a guidepost for determining whether an issue or positional conflict exists in the litigation or lobbying arenas. First, is the issue critically important to both representations? Second, will the determination of the issue in one representation affect its determination in the other representation? Third, will the competing interests materially limit the lawyer's representation of one or both clients? Unfortunately, issue or positional conflicts of interest are difficult to identify because they will often elude conflict-checking procedures targeting categories of

487. Id.

488. R. David Donoghue, Conflicts of Interest: Concurrent Representation, 11 GEO. J. LEGAL ETHICs 319, 325 (1998); John S. Dzienkowski, Positional Conflicts of Interest, 71 TEX. L. REV. 457, 460, 466-67, 498-500 (1993).

489. See, e.g., D.C. Op. 265, supra note 471 (advising that a lawyer may not take legal positions on behalf of a foster parents association, either legislatively or in litigation, that are inconsistent with positions taken by the attorney's individual clients - whether neglected children or foster parents-in unrelated matters without all affected clients' informed consent); Mich. State Bar Comm. on Prof'l \& Judicial Ethics, Op. RI-331 (2003), https://www.michbar.org/opinions/ethics/ numbered_opinions?O pinionID=1201\&Type=4 [https://perma.cc/D3H2-FHDS] (advising that a lawyer who serves as a member of a legislative body while representing clients may face positional conflicts if, in carrying out the lawyer's legislative duties, the lawyer-legislator supports action contrary to the lawyer's client's interests); Vt. Bar Ass'n, Adv. Ethics Op. 2002-03, at 1 (2002), http://www.vtbar.org/UserFile s/Files/WebPages/Attorney\%20Resources/aeopinions/Advisory\%20Ethics\%20Opinions/Legislator/0 2-03.pdf [https://perma.cc/83HP-HJEN] (opining that one firm attorney may lobby the state legislature on clients' behalf while a second firm attorney serves as an elected state legislator, as long as the legislator-lawyer does not review or vote on any legislation as to which the firm lobbyist-lawyer has promoted on behalf of a client).

490. See D.C. Bar Legal Ethics Comm., Op. 344 (2008), https://www.dcbar.org/barresources/legal-ethics/opinions/opinion344.cfm [https://perma.cc/MKW2-LBZH] (concluding that under the D.C. Rules of Professional Conduct, a lawyer may lobby on particular issues on behalf of a client even if the lawyer knows that another current client—-through different counsel—is lobbying for the opposite result, provided that none of the other provisions of D.C. Rule 1.7 are triggered). 
information such as names of parties and other key players to a new matter. ${ }^{491}$ As a result, these conflicts may remain unnoticed unless raised by the lawyers involved, or worse, discovered by the affected clients. On a positive note, this type of material limitation conflict generally is capable of consent under Model Rule 1.7(b). ${ }^{492}$ Thus, where an issue or positional conflict is brought to the lawyer's attention amidst competing matters, the lawyer should be able to seek the clients' consent to proceed with the representations. ${ }^{493}$

\section{CONCLUSION}

Conflicts of interest affect all lawyers, regardless of practice area, but they often are an especially difficult challenge for environmental lawyers. Environmental lawyers must be sensitive to both concurrent and former client conflicts of interest, recognize them in a timely fashion, evaluate whether they may be cured by client consent, and then if they wish to go forward with the representation, obtain all affected clients' informed consent to the representation and confirm it in writing. This is often easier said than done. By tackling the core concepts governing concurrent and former client representations under Rules 1.7 and 1.9 of the ABA's Model Rules of Professional Conduct, this article attempts to shed some additional light on the common conflicts issues that environmental lawyers regularly confront. Without a doubt, understanding conflicts of interest is the first step toward avoiding them and, if necessary, curing them.

\footnotetext{
491. Douglas R. Richmond et Al., PROFESSiOnal Responsibility in Litigation 817 ( $2 \mathrm{~d}$ ed 2016).

492. See id. (observing that the clear consensus among the authorities to have considered the issue is that issue or positional conflicts are "inherently consentable").

493. Id.
} 